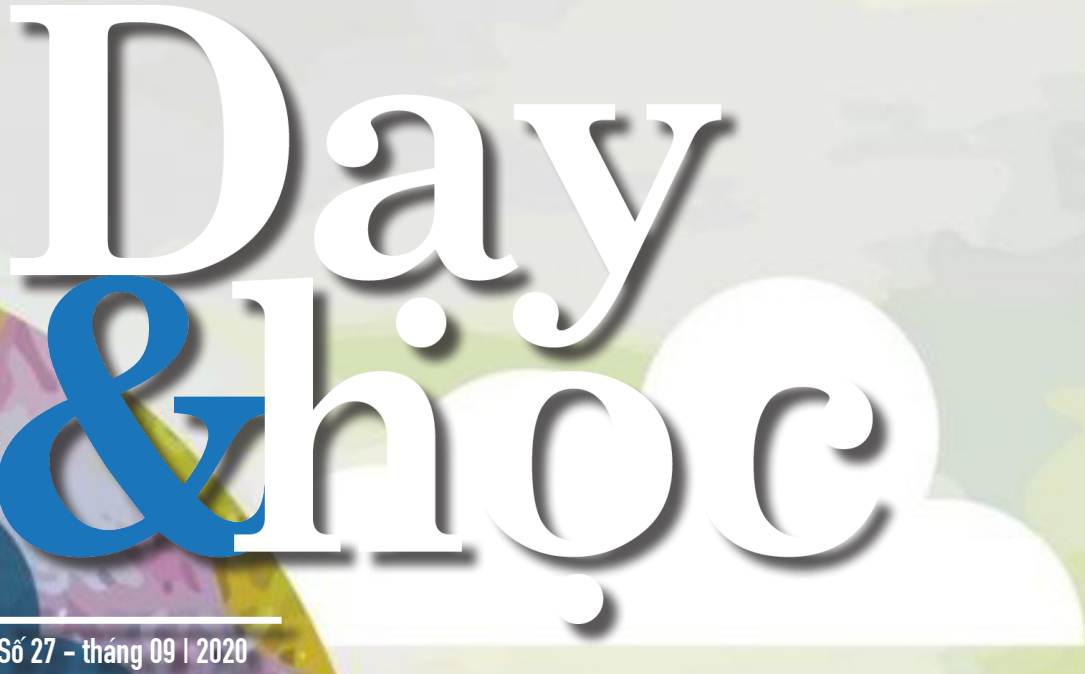

\title{
KHỞI ĐAีU
}

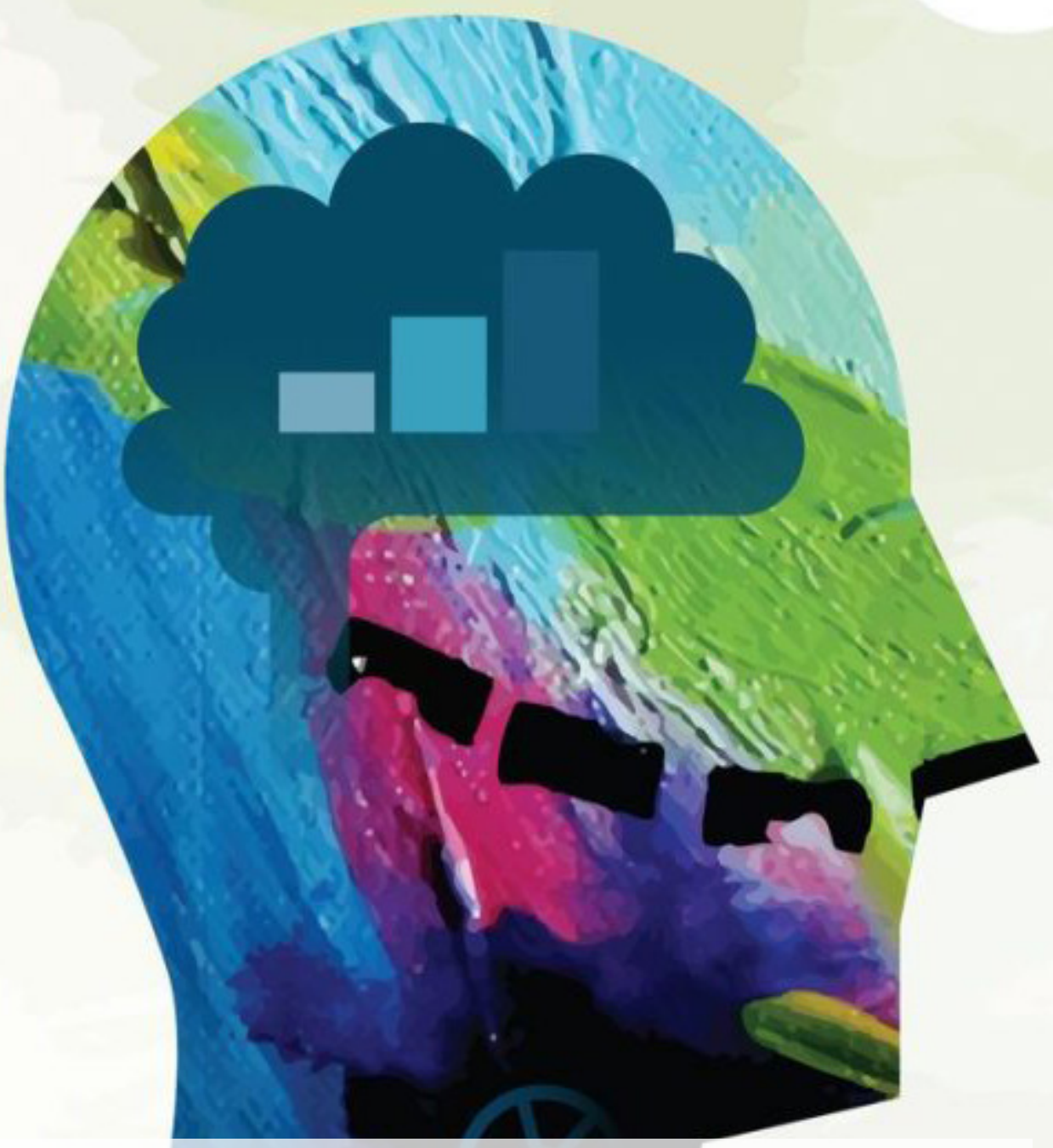

Lợl ÍCH LÂU DÀl CỦA GIÁO DỤC MẦM NON
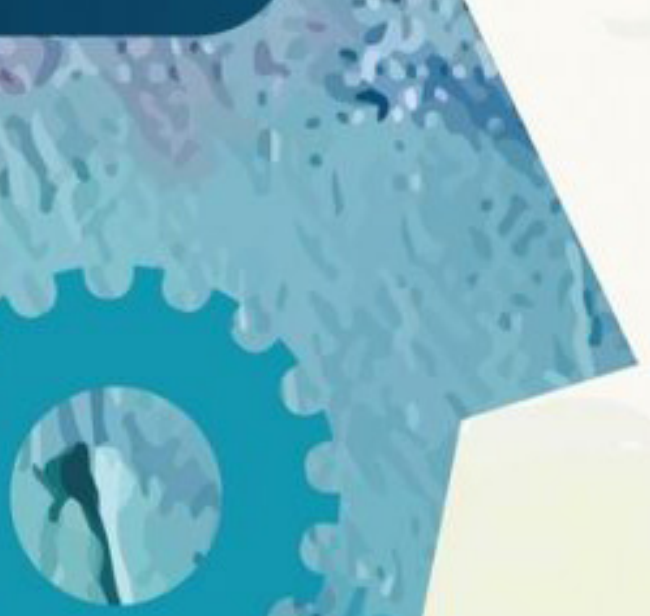

HİNH THÀNH TƯ DUY PHÊ PHÁN BẰNG CÁCH KẾT HợP HOẠT ĐộNG STEM VỚI LỊCH SỬ PHÁT TRIỂN KHOA HỌC
CHUYỂN SANG DẠY HOCC ĐẢO NGƯợC
CHÁNH NIỆM CÓ THỂ GIÚP GIÁO VIÊN VÀ HỌC SINH LÀM CHỦ ĐƯợC NHỮNG TìNH HUốNG ĐẦY THỬ THÁCH NHƯ THẾ NÀO? KHOAHOC 

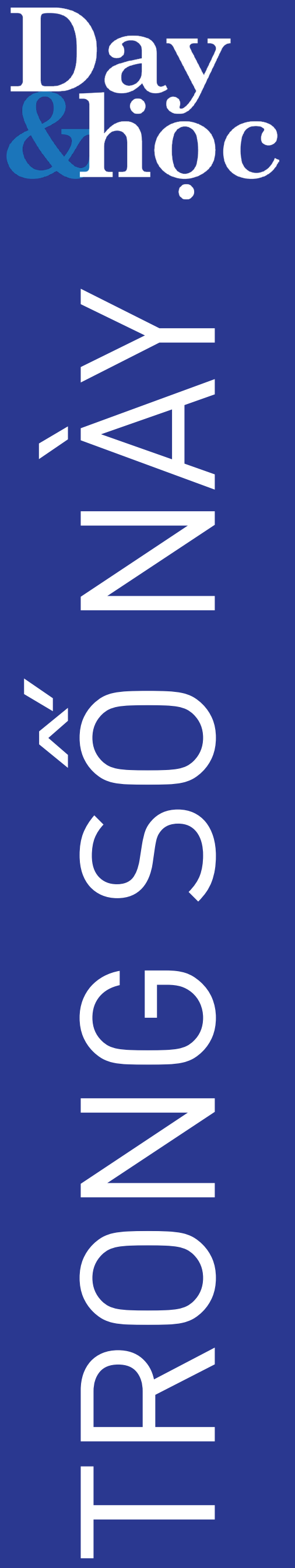


\section{Cải tổ giáo dục}

Lợl ÍCH LÂU DÀl CỦA GIÁO DỤC MÂMM NON

Hà Thanh Mai dịch

[30+ FRAMEWORKS GIÁO DUC] - KỲ 10 - KHUNG MESH VẾ TU DUY, CÁC KỸ NĂNG VÀ THÓI QUEN THIẾT YẾU. 41 Việt Anh

\section{Góc Nhìn}

GIÁO DỤC ĐẨU ĐỜl CHO TRÉ ĐA NGÔN NGŨ..................43 Ayden Lê dịch 


\section{Thể lệ gửi bài:}

Quý thầy cô, anh chị có nội dung liên quan tới Dạy và Học muốn chia sẻ tới cộng đồng, xin vui lòng gửi về Ban Biên tập Lộn xộn qua email bientap@day-hoc.org

Cuối bài viết, tác giả xin vui lòng giới thiệu vài nét về bản thân: Họ tên, nơi công tác, địa chỉ liên lạc, số điện thoại, các chủ đề nghiên cứu yêu thích...

Do thời gian và nhân sụ̣ có hạn, Ban Biên tập xin phép chỉ liên hệ với các bài viết được chọn đăng.

\section{Tinh thần 4.0}

Ban Biên tập và quý thầy cô, anh chị gửi bài cộng tác đều chia sẻ tinh thần 4.0, tức là:

- 0 lương

- 0 văn phòng

- O chuyên môn cao

- 0 gióri hạn không gian - thời gian

\section{Địa chỉ gửi bài:}

Bientap@day-hoc.org

\section{Chia sè:}

Quý thầy cô, anh chị cảm thấy nội dung Dạy và Học có ích, xin vui lòng chia sẻ tới bất kỳ những ai quan tâm, kèm theo trích dẫn nguyên vẹn và đầy đủ về nguồn gốc bài viết.

\section{Mọi người nói về Dạy \& Học}

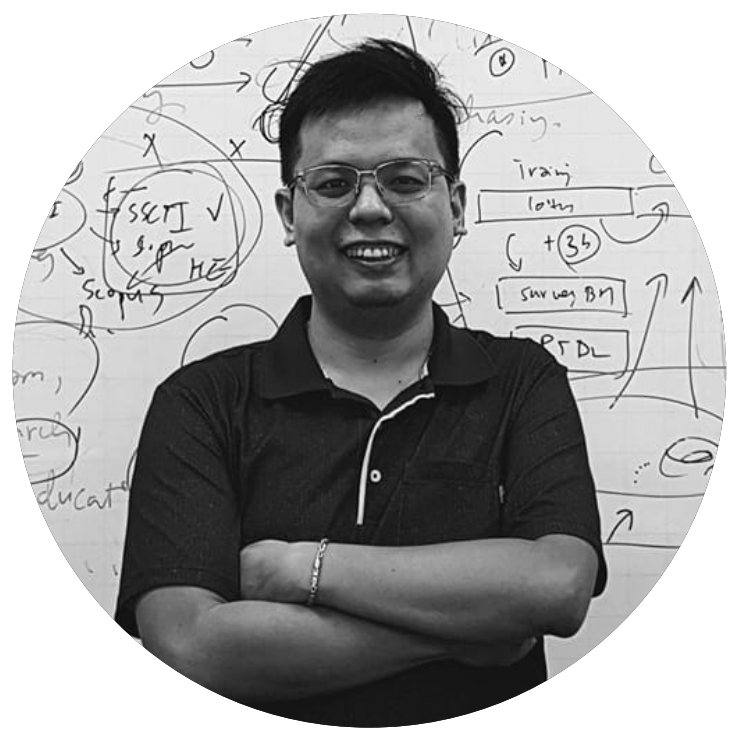

"Dạy \& Học là ấn phẩm không thể thiếu đối với các nhà trường phổ thông"

- TS Phạm Hiệp, Chuyên gia Giáo dục 


\section{Lời tựa}

Quý độc giả thân mến,

Vạn vật trong tự nhiên vẫn luôn vận hành theo một vòng quay, như mặt trời phải lặn và mặt trăng phải mọc, như mùa hạ đi để mùa thu tới, như chiếc hạt rơi cho một sự sống sắp nảy chồi. Sau một mùa hè muộn lặng lẽ thì mọi ngôi trường khắp cả nước giờ đây đã nhộn nhịp đi vào guồng quay vốn có. Dạy\&Học cũng không nằm ngoài quy luật đó. Đội ngũ Ban biên tập Thế hệ thứ Hai vừa tiếp nhận những thành quả của BBT Thế hệ thứ Nhất_những người mở đường tận tụy đã gắn bó với tập san hơn 2 năm qua. Dạy\&Học hôm nay lại tiếp tục cuộc hành trình với những người bạn mới. Vol 27 là một "khởi đâu" đối với đội ngũ ban biên tập Gen-2, một khởi đâu hân hoan mong được chia sẻ chút thông tin, kiến thức nhỏ nhoi tới mọi người. Dạ\&\&Học sẽ vẫn chạy tiếp vòng quay này. Cảm ơn bạn đọc đã ủng hộ và khích lệ ban biên tập bấy lâu nay. Dạy\&Học hy vọng sẽ vẫn nhận được sự chào đón của quý vị trong thời gian tới.

Trước hết, xin kính mời quý độc giả cùng dạo chơi một chuyến vào trong thế giới sinh vật học. Dạo chơi bằng cách nào? Bài “Chơi với sinh vật học" giới thiệu một công nghệ mới, cho phép người học được khám phá, nhập vai và đắm chìm vào thế giới của những tế bào thực vật; phá bỏ đi hàng rào ngăn cách giữa ngôn ngữ và thực tế. Một chuyến dạo chơi nữa, có lẽ sẽ khiến bạn nghĩ tới bộ phim "Ant-Man", thế giới của những hạt vật chất nhỏ xíu. Bài "Khoa học Nano" gợi ra những ý tưởng để đưa ngành khoa học nhỏ bé nhưng đầy lợi ích vào trong lớp học. Nếu đã đọc hai bài này, xin quý vị đừng bỏ qua ý tưởng “... kết hợp hoạt động STEM với lịch sử phát triển khoa học” vì đây là một cách tiếp cận phù hợp giúp thúc đẩy tư duy, khiến học sinh biết hoài nghi và đặt ra câu hỏi về thế giới quanh mình. Bàn về việc Dạy thế nào?, Dạy và Học kỳ này có đề cập tới mô thức “...dạy học đảo ngược” với nhiều ví dụ đa dạng, có thể áp dụng vào thực tế giảng dạy. Tất nhiên, để làm một điều mới thì phải đối mặt với nhiều khó khăn, chưa kể việc quản lý một lớp học vốn đã là chuyện đầy thử thách. Nếu bạn cảm thấy cần một giải pháp để bình tâm, tĩnh tại, Vol 27 có “Chánh niệm có thể giúp giáo viên và học sinh làm chủ được những tình huống đầy thử thách như thế nào". Còn nếu bạn đang có nhiều khó khăn trong dạy học trực tuyến, thì bạn có thể tham khảo “ 8 chiến lược nhằm cải thiện sự tham gia trong lớp học trực tuyến". Ngoài ra, chuyên mục Cải tổ giáo dục kỳ này có bàn tới những "Lợi ích lâu dài của giáo dục mầm non". Bài viết chỉ ra những khoảng trống trong nghiên cứu về các phương pháp giáo dục khi trẻ còn nhỏ tác động thế nào tới trẻ khi trẻ học lên cao. Và cuối cùng là một Góc nhìn về câu chuyện giáo dục “cho trẻ đa ngôn ngữ”, xoay quanh vấn đề xây dựng một môi trường học tập an toàn và đảm bảo sự phát triển phù hợp cho những đứa trẻ được sinh trong môi trường ngôn ngữ đa dạng.

Xin chúc Quý vị có những khoảng thời gian thú vị.

Trân trọng,

Ban Biên tập Lộn Xộn 


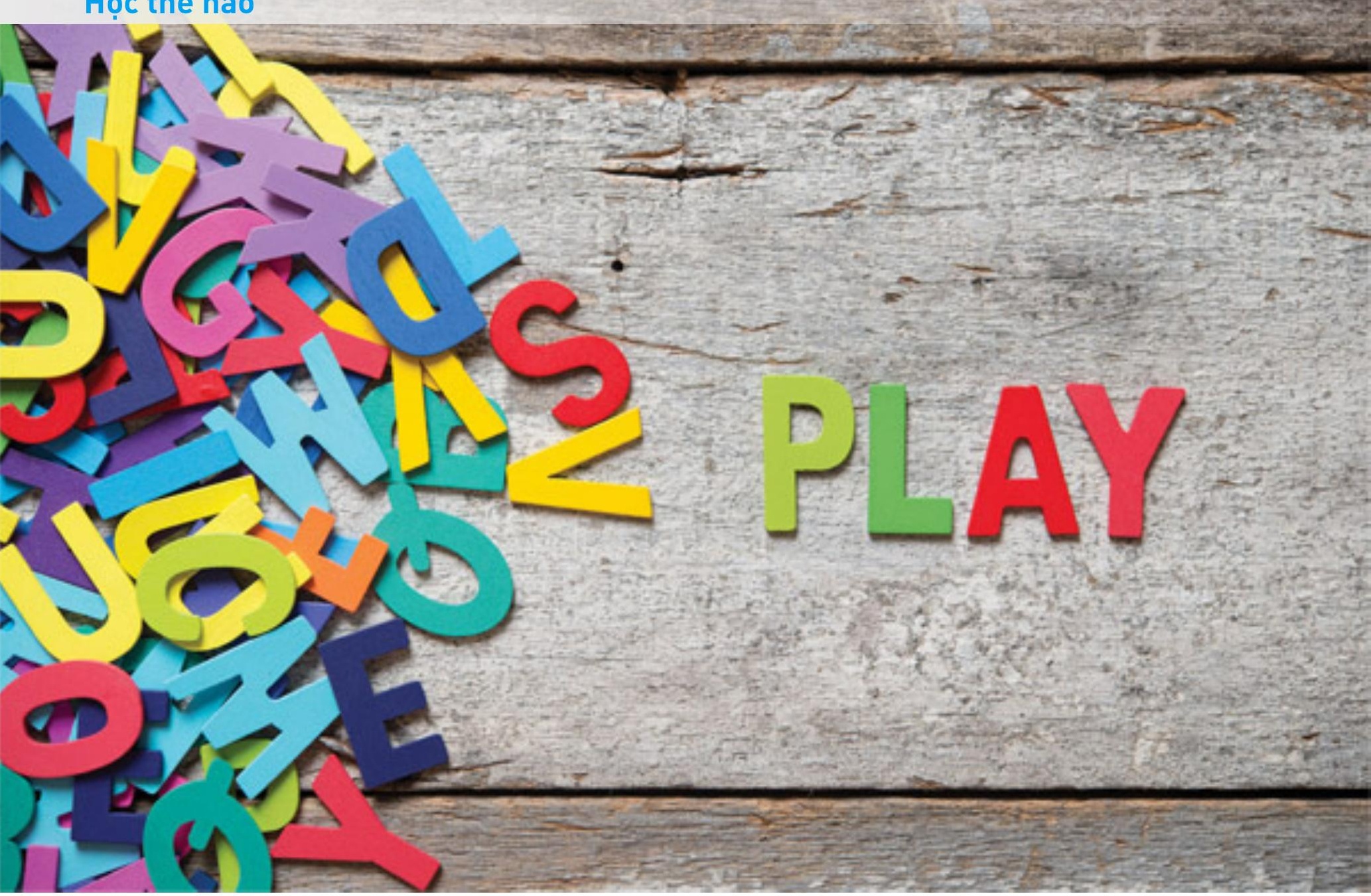

\section{Chở vở Sinh vật hoc}

'Lisa Tran/Phạm Mai Hằng dịch niệm khoa học dưới hình thức thật đáng nhớ và vui vẻ. Thời của Bill Nye đã qua lâu, nhưng nhu Bill Ney đã nói: "Science Rules” (Khoa học thật là tuyệt!)², và đó chính là lý do cho sự ra đời của Genomics Digital Lab (GDL)_một trò chơi tương tác trực tuyến dạy học sinh về bản chất tế bào sinh học có trụ sở tại Canada. Chương trình truyền hình của Bill Nye vẫn được nhớ đến ngày hôm nay bởi vì nó cung cấp nhiều lý thuyết và khái cầu về một nền tảng giảng dạy khoa học mang tính giáo dục thú vị vẫn tôn tại, đặc biệt bởi vì “học sinh thường phàn nàn rằng họ không thể thây mối quan hệ giữa các hoạt động của trường với cuộc sống thực tê" - theo Mark Oehlert, Trưởng khoa Trò chơi và Mô phỏng của Trường đại học Quốc phòng, phát biểu vào năm 2007.

1 Nguồn: https://teachmag.com/archives/1123 2 Bill Nye tên thật là William Sanford Nye (sinh ngày 27/11/1955). Ông là một nhà khoa học, kỹ sư, MC người Mỹ. Ông nổi tiếng với chương trình khoa hoc cho trè em: "Bill Nye the Science Guy" được phát sóng từ 1993-1998. Trong chương trinh này, cụm từ "Science Rules" được Nye nhắc đi nhắc lại rất nhiều lần. Trong tiếng Anh, "rules" có nghĩa là "quy tắc", "nguyên tắc", nhưng đồng thời nó cũng có nghĩa là "tuyệt vời", "tuyệt nhất".

Với sự phát triển của phần mềm đồ họa máy tính và công nghệ trò chơi, giờ đây việc tái tạo và mô phỏng nhiều lý thuyết hay mô hình khoa học thậm chí còn dễ dàng hơn. Nhưng có vẻ như công nghệ này được đầu tư rất hạn chế cho các sáng kiến về trò chơi giáo dục. Nhiều trò chơi trên thị trường hiện nay được bán dưới vỏ bọc "giáo dục”, 
nhưng tất cả đều chỉ là các trò chơi kèm theo nhiều vòng câu đố trắc nghiệm.

GDL không giống như bất kỳ trò chơi giáo dục nào như vậy. Nó thực sự thu hẹp khoảng cách giữa chơi và học. Khi bạn dạy môn Sinh học, là bạn đang kể một câu chuyện. GDL là một chuỗi các trò chơ được xây dựng xoay quanh câu chuyện về năng lượng - cách thực vật khai thác nó từ mặt trời, cách các tế bào sử dụng năng lượng đó và cách con người sử dụng năng lượng đó từ thực vật để làm thức ăn hay nhiên liệu. Nó đã nhận được nhiều lời tán dương bao gồm Giải thưởng Hội nghị thượng đỉnh của Liên hợp quốc trong hạng mục khoa học và công nghệ điện tử. GDL chứa 8 loại trò chơi độc đáo khác nhau có thể chơi bằng tiếng Pháp hoặc tiếng Anh.

Sinh vật học thường là một chủ đề khó nắm bắt bởi vì nó rất giống một khái niệm ba chiều mà chỉ được truyền tải hai chiều trong sách giáo khoa. Hình ảnh vượt quá khả năng mô tả của ngôn ngữ. GDL sử dụng đồ họa và hình ảnh động để giúp phá vỡ các rào cản xung quanh những khái niệm trừu tượng như: quang hợp, sao chép DNA và hình thành protein.

GDL sử dụng cách tiếp cận dựa trên khám phá, nhập vai. Ví dụ, học sinh có thể chơi một "trò chơi sinh vật học" và điều khiển các điều kiện xung quanh một thực vật đang sắp chết. Các em có được cảm giác thực sự về những gì sẽ xảy ra trong những tế bào bằng cách sử dụng các kỹ năng tư duy và sự sáng tạo của mình thay vì chỉ đọc một biểu đồ từ sách giáo khoa. GDL cho phép học sinh quan sát, kiểm tra, thao tác và trải nghiệm một số quá trình sinh học tự nhiên xảy ra trong cuộc sống thực hàng ngày; các quá trình mà các em không thể tự mình trải nghiệm hoặc hiểu được từ sách giáo khoa.

Các trò chơi từng được phát triển cho học sinh lớp 7 đến lớp 12 học môn Sinh học, dựa trên cơ sở thử nghiệm và khắc phục lỗi. Độ khó tăng dần theo từng cấp độ, giống như một trò chơi video. Để dành chiến thắng, người chơi cần phải học và để học họ cần thông tin thu được từ việc chơi trò chơi.

Đối với giáo viên và các nhà giáo dục, GDL là một phần bổ trợ hiệu quả cho lớp học. Giáo viên có thể đánh giá tiến bộ của học sinh vì nó được ghi lại trực tuyến theo thời gian thực. Kết quả của học sinh, thời lượng các em dành cho mỗi trò chơi và ghi chú của các em ghi trong sổ ghi chép trực tuyến đều có thể truy cập được.

Đối với học sinh, điểm lôi cuốn của GDL trong việc sao chép DNA chắc chắn không khác gì trò chơi Guitar Hero. Trò chơi này không chỉ hoạt động với một cây Guitar Hero thực tế có cắm USB, mà còn có cả âm nhạc của riêng người chơi. Trong thế hệ trò chơi video ngày nay, những người tạo ra GDL đã thực hiện mọi nỗ lực để làm cho sinh vật học thật sự sống động. Khoa học là điều tuyệt vời nhất!. 


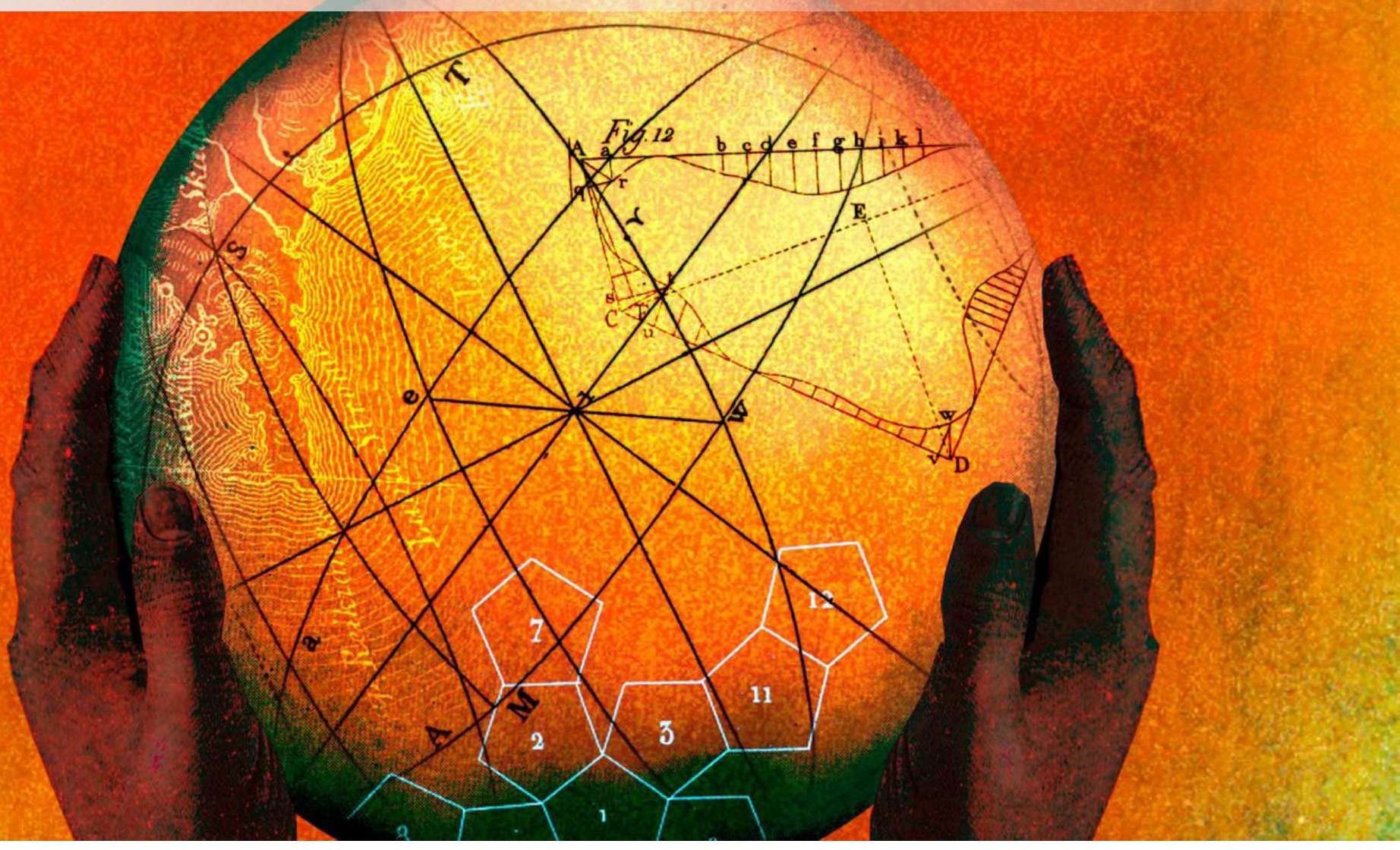

\section{Finh thành tur duy}

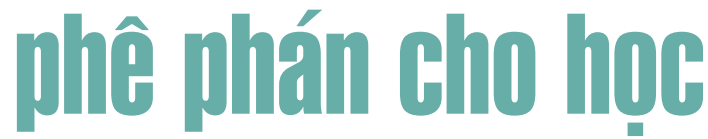

sinh hằng cách kết

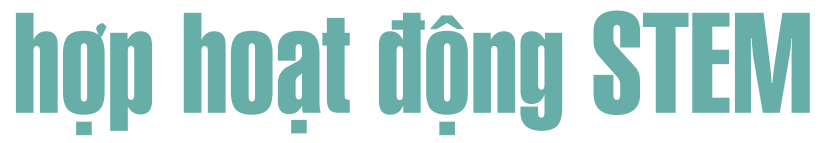

vớ lịch sử phát triển

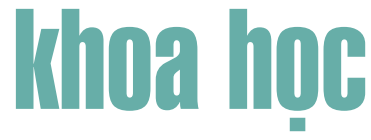

Ainissa Ramirez | Nguyễn Tiến Đạt dịch

Lời tựa: Bằng cách yêu cầu học sinh khám phá vê lịch sử các phát kiến khoa học, chúng ta có thể khiến các em biết hoài nghi, đặt ra nhiều thắc mắc hơn khi nhìn nhận thế giới xung quanh minh, và tạo điều kiện đề các em suy nghĩ về nguyên nhân và tác động.
Đối với nhiều giáo viên khoa học, mỗi buổi tối trước tiết học của ngày hôm sau luôn chất chứa ưu tư xuất phát từ mong muốn biến lớp học trở nên hấp dẫn hơn. Tuy nhiên, những công cụ mà họ sử dụng có thể không giống nhau.

Một vài giáo viên có đủ không gian sáng tạo được trang bị những chiếc máy in $3 \mathrm{D}$; vài người thì không. Một số giáo viên có nền tảng tri thức khoa học vững chắc, còn số khác thì không. Một vài trường có trang bị đây đủ các bình thí nghiệm và kính hiển vi hiện đại, nhưng nhiều nơi khác thì không. Thông qua các hoạt động STEM, tất cả học sinh đều có cơ hội để phát triển tư duy phê phán. Nhưng việc phát triển loại hình tư duy trên không đơn thuần đến từ một không gian sáng tạo hoành tráng, một tấm bằng khoa học uy tín hay nguồn tư liệu dồi dào.

Một trong những cách thức đột phá để khuyến khích tư duy phê phán trong STEM đó là thêm vào đó một chút yếu tố của lịch sử. STEM được ra đời từ mong muốn tái tạo phương thức vận hành của cuộc sống bằng cách kết hợp bốn yếu tố cốt lõi: Khoa học, Công nghệ, Kỹ thuật và Toán. 
Trong thực tiễn, những yếu tố trên thường kết hợp với nhau một cách liền mạch và ít tạo được sự chú ý nhất định.

Nếu muốn chuẩn bị cho những đứa trẻ trở thành những nhà khoa học trong tương lai thì chúng ta cần cho các em biết tường tận về quá khứ. Bằng cách làm như vậy, chúng ta có thể làm sáng tỏ những tiến bộ của khoa học thông qua việc cho học sinh hiểu những sự kiện lộn xộn đã thực sự diễn ra trong lịch sử. Đồng thời, chúng ta chỉ cho các em thấy khoa học đã thực sự được khám phá như thế nào và cũng là cơ hội để vinh danh các nhà khoa học đã viết nên lịch sử của nhân loại, dẫn dắt các em học sinh vào thế giới của khoa học.

\section{SỨC MẠNH CỦA NHŨNNG CÂU CHUYỆN KHOA HỌC}

Một trong những cách để chia sẻ khoa học từ điểm nhìn của lịch sử là kể những câu chuyện thật hay về chúng. Những câu chuyện đáng nhớ: Nhiều nghiên cứu đã chỉ ra rằng con người luôn phản ứng một cách tự động với cách tiếp cận trên, và tạo nền móng ban đầu cho những thông tin - ví dụ, bằng cách trình bày những khám phá khoa học dưới hình thức tường thuật một cách thuyết phục - giúp não bộ kết hợp những khái niệm mới. Bằng cách này, câu chuyện diễn ra liền mạch như một hệ băng chuyền, giúp giờ học trở nên thú vị và qua đó truyền tải được những thông tin quan trọng.

Không dừng lại ở đó, một câu chuyện hay cũng có thể được sử dụng cho những mục đích khác. Bằng cách nhìn nhận tác động của các phát minh trong quá khứ đến cuộc sống trong hiện tại, học sinh học được cách nhìn nhận vấn đề tổng thể. Ví dụ, nếu các em được chỉ ra tác động của đông hồ đến cuộc sống hoặc cách máy tính thay đổi tư duy của con người, thì các em có thể thấy được công nghệ đã định hình văn hoá hoặc thậm chí thay đổi cảm nhận của chúng ta về thời gian như thế nào. Bằng cách này, STEM vượt xa những hạn chế điển hình của nó và tạo thành mối liên kết trong suy nghĩ của học sinh - không những liên quan đến những công nghệ khác mà còn tất cả các khía cạnh và lĩnh vực của quá trình học hỏi.

\section{KHÁM PHÁ NHỮNG HỆ QUẢ KHÔNG CHỦ ĐỊNH CỦA NHỮNG PHÁT MINH}

Trong hơn một thập kỷ qua, tôi đã tìm kiếm một quyển sách có thể cung cấp cả bối cảnh lịch sử và bối cảnh xã hội của những phát minh để kể về các câu chuyện khoa học nhưng lại không có nhiều may mắn lắm. Tôi cảm thấy tầm quan trọng của cách tiếp cận bị bỏ sót này với việc nuôi dưỡng những người có tư duy phê phán, bởi lẽ đó tôi quyết định viết cuốn The Alchemy of Us (Thuật giả kim của chúng tôi), quyển sách hàm chứa những phát minh và cách thức chúng thay đổi cuộc sống và xã hội. Trong quyển sách, những cuộc sống của vô số nhà phát minh ít được biết đến (từ mục sư Hannibal Goodwin' đến người nội trợ Bessie Littleton²) đều được tiết lộ, và có rất nhiều cách để những phát minh thường ngày thay đổi cuộc sống được làm sáng tỏ.

Thinh thoảng kết quả của những phát minh trên được chú ý và cũng có nhiều trường hợp không được chú ý đến. Ví dụ, học sinh có thể nhìn thấy những bức điện báo được sử dụng điện để truyền tải thông tin từ một khoảng cách vô cùng xa trong một thời gian ngắn. Tuy nhiên, chúng có thể nhận thấy việc gửi những bức điện báo còn tồn tại nhiều thiếu sót: Nó không thể chứa được nhiều nội dung trong cùng một khoảng thời gian. Khách hàng tại bưu cục được khuyến khích gửi những tin nhắn ngắn gọn. Chẳng bao lâu, những tờ báo được truyền tải bởi điện báo trong các tòa soạn, và biên tập viên yêu cầu phóng viên đưa ra những bài viết thật cô đọng. Việc sử dụng những tuyên ngôn ngắn gọn đã trở thành phong cách

$1 \quad$ Hannibal Goodwin (1822 - 1900) là người phát minh ra màng phim trong suốt được sử dụng trong máy ghi quay phim đầu tiên của Thomas Edison.

2 Bessie Littleton (vợ của nhà vật lý Jesse Littleton) đã đưa ra kiểm chứng thủy tinh có thể sử dụng trong lò nướng. 
báo chí của một phóng viên đã viết rất nhiều bài báo nổi tiếng - tên là Ernest Hemingway.

Ví dụ trên đã mô tả cách thức ra đời của công nghệ, điện báo, một loại ngôn ngữ thay thế, dẫn đến phương thức hành văn được sử dụng nhiều nhất trên thế giới - và những kết quả to lớn và không thể dự đoán trước được của bài học trên, chúng ta có thể đối chiếu được với cái cách mà Twitter và tin nhắn thay thế ngôn ngữ ngày nay. Khi lịch sử được tích hợp trong STEM, học sinh không chỉ học về khoa học mà còn biết được những tác động rộng rãi của khoa học đến cuộc sống.

\section{ĐịNH HìNH TƯớNG LAI BẰNG QUÁ KHỨ: MộT BÀl TẬP}

Một trong những cách có thể tạo dựng kỹ năng tư duy phê phán chính là soi chiếu công nghệ ở cấp độ vi mô. Hãy để học sinh suy nghĩ về các phát minh, ví dụ như những chiếc điện thoại của các em hoặc Instagram hoặc mạng Internet, và chú ý đến cách thức chúng tác động một cách rộng lớn đến cuộc sống. Học sinh có thể tạo ra một danh sách những thay đổi lyêu cầu các em không chỉ nghĩ về những thay đổi về mặt vật chất mà còn thay đổi về cả những ý tưởng, khái niệm trừu tượng như tâm lý của con người hay hệ thống niềm tin) chia học sinh thành các nhóm nhỏ để thảo luận và chia sẻ những gì chúng có thể tìm thấy được. Thêm vào đó, bạn có thể đưa ra những sự kiện phản thực tế: Yêu cầu học sinh tạo ra một trục thời gian về lịch sử của một phát minh cùng với một trục thời gian thứ hai giả tưởng rằng phát minh đó chưa bao giờ xuất hiện. Điều gì sẽ xảy ra nếu điện thoại đã chưa bao giờ được phát minh?

Dĩ nhiên là không có câu trả lời đúng hoặc sai, nhưng những nhiệm vụ sẽ khiến cho học sinh quan sát thế giới một cách hoài nghi hơn - tràn đầy những thắc mắc - và tạo điều kiện để các em suy nghĩ đến những nguyên nhân và tác động.

Để nhìn nhận vấn đề một cách sâu sắc hơn: Hãy bắt đầu bằng việc yêu cầu học sinh kiểm chứng những tác động của internet đến cuộc sống hiện đại. Mạng internet chắc chắn đã đem lại những thay đổi to lớn đến cuộc sống. Trước hết, chúng ta có thể nghe nhạc, xem video, truy cập thông tin và liên lạc với nhau một cách dễ dàng. Hãy để học sinh có bàn luận về cuộc sống trước và sau khi có mạng internet theo nhóm và sau đó tạo ra bản vẽ hoặc viết lại một bài luận ngắn. Chúng có thể trả lời những câu hỏi như sau: Con người tìm kiếm thông tin như thế nào? Mọi người nghe tin tức của nhau như thế nào? Mọi người nghe nhạc như thế nào? Thông tin về những chủ đề khác nhau được lưu trữ ở đâu trước khi có internet? Bước tiếp theo có thể tìm kiếm những ưu và nhược điểm của internet, đặc biệt là mạng xã hội. Liệu việc kết nối thông tin đang giúp đỡ hay làm tổn thương chúng ta? Liệu mạng internet đem chúng ta lại gần nhau hơn hay chia rẽ chúng ta? Liệu mạng internet khiến chúng ta dễ dàng hơn hay cản trở chúng ta trong việc tìm ra sự thật?

Một khi học sinh đã được dẫn dắt để suy nghĩ về công nghệ theo hướng này, bạn có thể yêu cầu học sinh thử sức với vai trò của một nhà tiên tri. Yêu cầu các em suy nghĩ đến những câu hỏi có tính gợi mở như: Nếu mạng xã hội dựa trên những lượt thích ("likes") và lượt theo dõi ("follows") thì hình thái xã hội trong tương lai sẽ diễn ra như thế nào? Chúng ta nghe theo những người nổi tiếng với vài triệu người theo dõi hay những lời khuyên từ chuyên gia với ít lượt theo dõi hơn? Liệu thông tin sai lệch có bị phát tán một cách dễ dàng? Học sinh có thể vẽ một bức tranh, viết một bài luận ngắn hoặc tạo nên một video để phản ánh những tác động của internet lên toàn xã hội và cuộc sống sẽ được hình dung như thế nào trong tương lai nếu có hoặc không có những giải pháp được đưa ra.

\section{KẾT NỐI NHỮNG CÔNG DÂN TƯƠNG LAI}

Trong khi các kĩ năng STEM ngày càng đóng vai trò quan trọng trong thế giới công nghệ hiện đại, 
STEM cũng được coi là con đường khuyến khích học sinh trở thành người có tư duy phê phán, và đồng thời trở thành một công dân tương lai. Bằng cách đặt khoa học trong bối cảnh lịch sử và văn hóa rộng hơn, chúng ta có thể lưu ý học sinh cách thức các phát minh khoa học trở thành một phần trong quá trình tiến hóa của nền văn minh và thậm chí hệ thống niềm tin về giá trị đạo đức. Và bằng cách cho học sinh đủ không gian để phê phán những phát minh, chúng ta cho chúng những kỹ năng để định hình tương lai.

Tuy vậy, để những đứa trẻ đặt ra các câu hỏi mang tính thách thức, thì chìa khóa của bước đầu tiên là đưa cho các em những câu chuyện khoa học hấp dẫn. Một khi học sinh đã trở nên hứng thú với cách thức STEM trở thành một phần mảnh ghép của bức tranh tông thể, các em sẽ có những kỹ năng để nhìn thế giới rõ ràng hơn và sẽ có những lăng kính cần thiết để bắt đầu đặt ra những câu hỏi hóc búa. Cách tiếp cận này có điểm tương đồng với sự thông thái của William Shakespeare, người mà một vài thập kỷ trước đã nói rằng, “Quá khứ là lời mở đầu”. Ông ấy đã hoàn toàn đúng, bởi nếu chúng ta quan sát thật kỹ lưỡng, những câu chuyện trong quá khứ cho chúng ta những chỉ dẫn hay để tiến về phía trước.

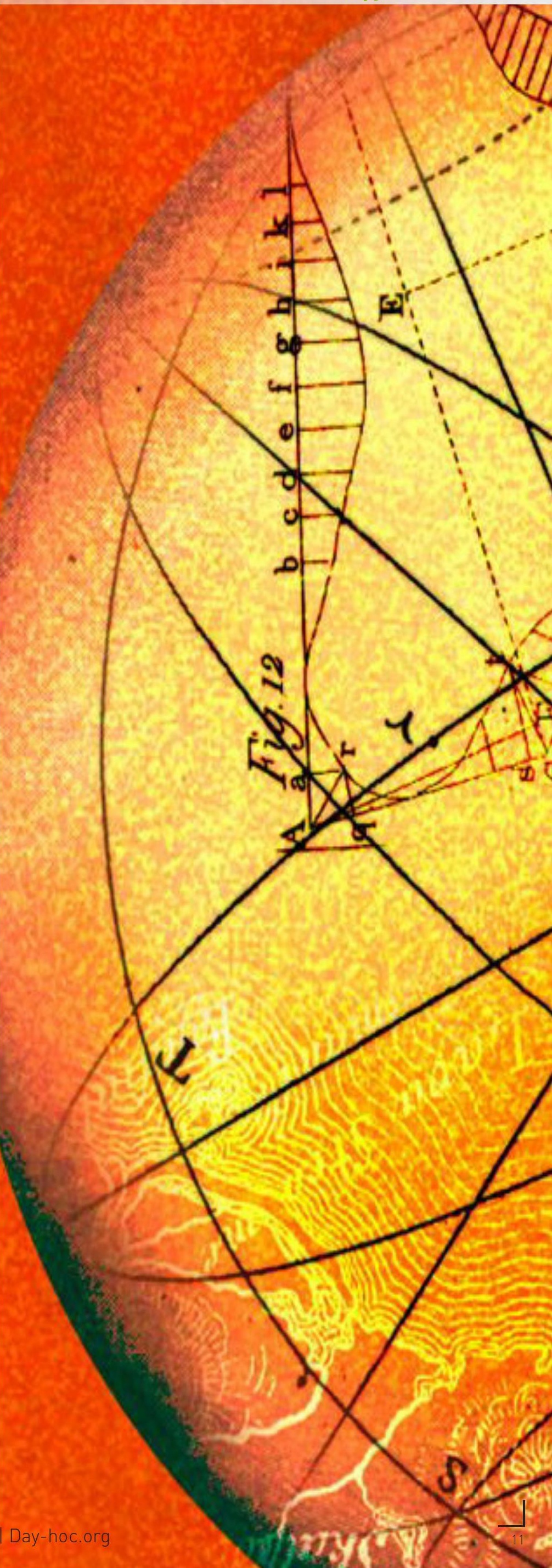




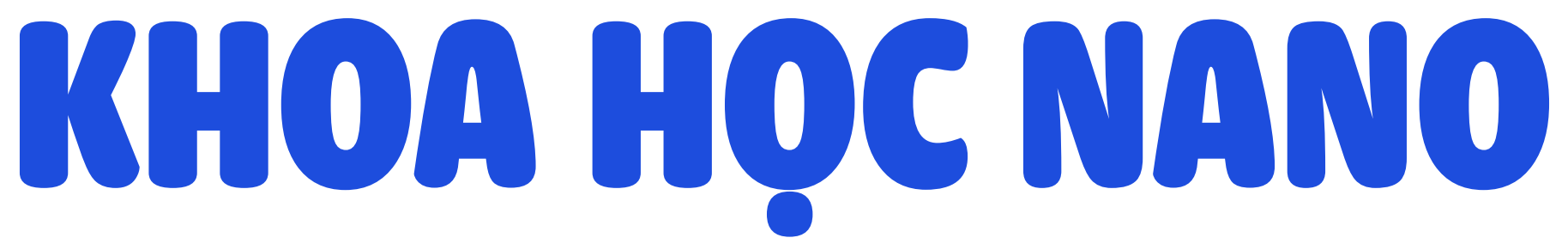

By Lisa Tran

| Chương Nguyễn dịch

Thế giới đang bắt đầu cuộc hành trình xuyên suốt Thời đại Nano. Việc giảng dạy công nghệ nano cho học sinh, sinh viên mở ra con đường, dẫn các em đến một thế giới nơi công nghệ nano đang trở thành ngành khoa học thống trị.

Thế giới Nano, nghe có vẻ như chỉ tồn tại trong trí tưởng tượng của những nhà văn khoa học viễn tưởng. Đó là một thế giới với các cửa sổ tự làm sạch và các vật liệu “cứng hơn kim cương” và “mạnh hơn thép với trọng lượng chỉ bằng một phần nhỏ". Nhưng thế giới này rất thực và người dẫn dắt chuyến tham quan của chúng tôi là Deb Newberry', một nhà vật lý hạt nhân và nhà khoa học công nghệ nano tại Trường Cao đẳng Kỹ thuật Dakota, Rosemount, Minnesota. Trong cuốn sách đồng tác giả của Newberry, Điều lớn lao tiếp theo thực sự nhỏ: Công nghệ nano sẽ thay đổi tương lai doanh nghiệp của bạn như thế nào, cô ây mô tả công nghệ nano là “nghệ thuật và khoa học về thao tác và sắp xêp lại các nguyên tử và phân tử riêng lẻ để tạo ra các vật liệu, thiết bi hữu ích và hệ thống."

Công nghệ nano hay khoa học nano, được gọi như vậy bởi vì các nguyên tử và phân tử rất nhỏ - có kích thước cỡ nanomet (nm) trong đó 1nm bằng một phần tỷ mét $(\mathrm{m})$. Để hiểu rõ hơn về kích thước nano, chúng ta có thể bắt đầu bằng cách so sánh một sợi tóc người với các nguyên tử vàng. Một sợi tóc người đường kính khoảng

1 Deb Newberry, Nhà vật lý hạt nhân và nhà khoa học công nghệ nano tại Trường Cao đẳng Kỹ thuật Dakota, Rosemount, Minnesota. 7000nm trong khi kích thước của hai nguyên tử vàng rưỡi là $1 \mathrm{~nm}$. Và như tên gọi của nó, khoa học nano là khoa học về kích thước rất nhỏ.

Nhà khoa học thực thụ, có trách nhiệm không dựa vào sự quan sát đơn thuần. Trên thực tế, các nhà khoa học nano đã tái tạo thành công cấu trúc nguyên tử của một số vật liệu bên và cứng nhất trên Trái đất và sửa đổi chúng để tạo ra những cấu trúc mạnh hơn và đàn hồi hơn. Nhiều nhà phân tích bên ngoài lĩnh vực khoa học đã ủng hộ khoa học nano vì tiềm năng lớn của nó. Nhà đầu tư mạo hiểm, Steve Jurvetson của Draper, Fisher và Jurvetson tin rằng: "công nghệ nano là làn sóng công nghệ vĩ đại tiếp theo, mối liên hệ của sự đổi mới khoa học tạo nên cuộc cách mạng cho hầu hết các ngành công nghiệp và ảnh hưởng gián tiếp đến cấu trúc xã hội. Các nhà sử học sẽ nhì lại kỷ nguyên sắp tới không kém phần hào hùng so với Cách mạng Công nghiệp".

Đối với phần còn lại của xã hội, chúng ta bi ảnh hưởng bởi công nghệ nano vì qua hàng chục năm thử nghiệm trong các phòng thí nghiệm, công nghệ nano đã nhanh chóng hiện thực hóa thành các sản phẩm hàng ngày. Ví dụ, về dụng cụ thể thao. Trong môn thể thao như quần vợt, một cây vợt mạnh hơn sẽ đây bóng đi xa hơn, nhưng để có cây vợt như thế các vật liệu tạo nên sẽ rất nặng. Với công nghệ nano, các nhà khoa học có thể chế tạo chiếc vợt mới mạnh hơn nhưng nhẹ hơn vợt truyền thống bằng siêu vật liệu như ống nano carbon. Các nhà khoa học nano cũng đã tạo ra "siêu bóng" tennis_những quả bóng tennis nảy tốt hơn. Các sợi của quả bóng được thu nhỏ lại tới kích thước nm và được thêm các lớp phủ bên ngoài. Các sợi này rất nhỏ nên chúng 
được dệt chặt chẽ với nhau hơn so với các sợi thông thường. Các quả bóng quần vợt mới hiện nay có ít kẽ hở hơn để giữ cho không khí không thoát ra ngoài, giữ được độ nảy của bóng trong thời gian dài hơn.

Nhiều ứng dụng công nghệ nano đã được kết hợp một cách sáng tạo vào ngành mỹ phẩm. Kẽm oxit là thành phần bí mật trong kem chống nắng giúp bảo vệ da khỏi tia UV của mặt trời. Các hạt oxit kẽm có màu trắng, nhưng khi kích thước của chúng được giảm xuống cõ̃ $n m$, chúng có vẻ trong suốt. Bây giờ chúng ta có thể mua kem chống nắng “không còn là màu trắng mà bạn thường thấy, nhưng chức năng bảo vệ giống hệt nhau."

Đáng ngạc nhiên là chất lượng thực phẩm cũng có thể được cải thiện với sự hỗ trợ của công nghệ nano. Newberry kể lại: "Tôi nhớ lần đầu tiên nhìn thấy sữa chua ít béo có kết cấu dạng nước. Chất béo là một chất nhũ hóa, nó tạo cho thực phẩm độ sánh mịn", vì vậy ít chất béo hơn có nghĩa là kết cấu sẽ thô hơn. Để giải quyết vấn đề hóc búa về thực phẩm này, các nhà sản xuất hiện đang tìm cách thu nhỏ các hạt chất béo trong các sản phẩm ít chất béo. Thực phẩm vẫn chứa ít chất béo, nhưng kết cấu mới mịn hơn vì chất béo hầu như không nhìn thấy được. Thơm ngon và bổ dưỡng.

Công nghệ nano bao gồm một quá trình phát triển liên tục trong các phòng thí nghiệm hiện đại và trong các nhà sản xuất. Newberry nói: “Những khám phá mới nhất đang thực sự được thực hiện trong các sản phẩm và sản xuất, đó là nơi sẽ có một loại công việc hoàn toàn mới: sản xuất, thử nghiệm và đảm bảo chất lượng." Dean Hart của Nanolnk, một công ty công nghệ nano, tuyên bố rằng Hiệp hội Khoa học Quốc gia ước tính sẽ cần hai triệu nhà công nghệ nano vào năm 2015. "Hiện tại, trên thế giới chi có khoảng 20.000 chuyên gia nano. Nhu cầu về nhiều chuyên gia hơn trong một khoảng thời gian ngắn là quá sức", nhưng chúng ta có thể bắt đầu đào tạo các nhà công nghệ nano tương lai bằng cách giảng dạy khoa học cho những học sinh, sinh viên ham học hỏi ngày nay.

Trong hầu hết các lĩnh vực khoa học, nghiên cứu thực hành truyền thống đã được dành cho các viện nghiên cứu chuyên môn cao. Tuy nhiên trong khoa học nano, sinh viên có thể tự tiến hành nghiên cứu và đóng góp vào lượng tri thức ngày càng tăng lên thông qua các thí nghiệm của chính mình. Sinh viên quan tâm đến công nghệ nano, có khả năng, có thể chuyển niềm đam mê của họ thành một nghề nghiệp cụ thể. Sinh viên khoa học nano có thể bắt đầu học chuyên sâu ngay từ cấp trung học.

Giảng dạy khoa học nano có thể là một nhiệm vụ khó khăn, nhưng nó chắc chắn không đòi hỏi phải phát triển một khóa học hoàn toàn mới. Newberry gợi ý rằng “các khái niệm công nghệ nano có thể được đưa vào kế hoạch dạy học bằng cách thêm một bước thảo luận khác hoặc thực hiện các sưra đổi nhỏ". Newberry có kinh nghiệm giảng dạy công nghệ nano cho những người trẻ tuổi trong khuôn khổ trại hè hàng năm dành cho học sinh trung học tại Trường Cao đẳng Kỹ thuật Dakota.

Việc đưa công nghệ nano vào chương trình giảng dạy môn Khoa học có thể đơn giản hóa như:

\section{Hóa học}

Nếu bạn đang hướng dẫn một thí nghiệm liên quan đến việc đun sôi và trộn để tạo kết tủa, bạn không cần phải thêm một thí nghiệm khác, thay vào đó, bạn hãy thêm một bước khác. Bạn có thể thay thế các hóa chất thông thường bằng các hóa chất khác một cách dễ dàng. Sau đó, học sinh có thể lấy một dung dịch đã có vàng trong đó, tách các nguyên tử vàng và nhóm chúng lại với nhau. Trong quá trình này, các em sẽ tạo ra các nguyên tử nano vàng. Chúng sẽ tạo thành dung dịch màu đỏ và khi thêm muối vào, dung dịch chuyển sang 
màu xám vì bạn đang thay đổi kích thước hạt. Newberry cho biết: “Các sinh viên sau đó sẽ tạo ra các hạt nano vàng thay vì thứ kết tủa màu trắng rờ xuống đáy ống nghiệm. Sau đó, các em có thể sư dụng kính hiển vi để đo và quan sát thấy rằng đây không phải thuật giả kim nhưng các em vẫn đang làm ra vàng!."

\section{Vật lý}

Khi sinh viên đang nghiên cứu về vận tốc, ví dụ kinh điển là trường hợp nước chảy ra từ vòi. Các em được yêu cầu tính toán vận tốc của nước. Giáo viên có thể thêm một bước nữa và yêu cầu học sinh quan sát dòng chảy của chất lỏng nếu một ống hút được gắn vào vòi. Khi làm như vậy, giáo viên có thể giới thiệu cho học sinh ý tưởng về chất lỏng chảy qua ống mao dẫn. “Đó không phải là những nguyên tử có kích thước nano, nhưng nó khá gần gũi và tương tự" - Newberry giải thích và tâm trí của họ đang nghĩ về dòng chất lỏng ở cấp độ vi mô.

Sự tham gia và các cơ hội thực hành là điều tối quan trọng trong việc học tập và lĩnh hội khoa học của học sinh, sinh viên. Các em được kích thích và thử thách khi được học thông qua hoạt động trải nghiệm. Công nghệ nano hoàn hảo cho các lớp học vì cốt lõi của hoạt động thực hành của nó xoay quanh nhiều mô-đun thực hành. Thật may mắn, những người trong lĩnh vực công nghệ nano cam kết thúc đây khoa học đến nhiều tầng lớp xã hội bao gồm cả các nhà giáo dục.

Một máy chế tạo nano, một công cụ quan trọng trong khoa học nano, thường yêu cầu một phòng sạch để vận hành, "có thể cần 80-100 triệu đô la để xây dựng và bảo trì. Ai có thể mua được chứ?" - Hart than thở. "Chúng ta cần tìm cách đặt các công cụ trong lớp học”, đó chính là lý do Nanolnk đã phát triển NanoProfessor Suite. Đây là một bộ thiết bị và chương trình giảng dạy được thiết kế cho trường trung học và không yêu cầu phòng sạch. Mọi thứ bạn cần để bắt đầu giảng dạy khoa học nano đều có trong gói. NanoProfessor gồm ba thiết bị: NLP 2000, một máy đúc nano để bàn; Kính hiển vi lực nguyên tử quan sát hình ảnh vật chất rắn; và Kính hiển vi huỳnh quang quan sát hình ảnh vật liệu sinh học như DNA, vi rút và vi khuẩn. Ngoài ra còn có một sách giáo khoa chuyên sâu hỗ trợ; tất cả các vật liệu cần thiết để tiến hành phòng thí nghiệm; tài liệu hỗ trợ giảng dạy gồm đánh giá, chấm điểm, hướng dẫn và trình bày bài giảng... và quan trọng nhất là được đào tạo về thiết bị, giáo trình và phòng thí nghiệm. Điều duy nhất còn thiếu là bạn.

Sự tiến bộ của công nghệ nano đã bị cản trở do thiếu các thiết bị tinh vi, nhưng ngay sau khi máy móc mới được phát triển, các nhà khoa học đã lập tức tiến hành các thử nghiệm. Mặc dù khoa học nano vẫn đang trong giai đoạn nghiên cứu, nhưng các ứng dụng của nó đã trải dài trong các lĩnh vực tiêu dùng, sản xuất và sẽ sớm xuất hiện trong các trường học. Công nghệ nano đang thay đổi bộ mặt của khoa học, cách chúng ta sống và thế giới mà chúng ta đang sống. Giờ đây, chúng tôi có thể cải tiến máy móc và vật liệu bằng cách làm cho chúng mạnh hơn, nhanh hơn, hiệu quả hơn và nhỏ hơn. Không có ngành nào không thay đổi. Khi công nghệ nano cách mạng hóa xã hội của chúng ta, các nhà khoa học nano sẽ nỗ lực đồng hành cùng các nhà giáo dục. Với các nguồn lực thích hợp, chúng tôi có thể dẫn dắt sinh viên của mình trong hành trình khám phá lĩnh vực khoa học mới này và đảm bảo vị trí của họ trên hành trình xuyên suốt Thời đại Nano.

Tìm hiểu thêm thông tin tại

Dakota County Technical College: https://www.dctc.edu/ NanoProfessor: http://www.nanoprofessor.net/

Nanolnk: http://www.nanoink.net/ 


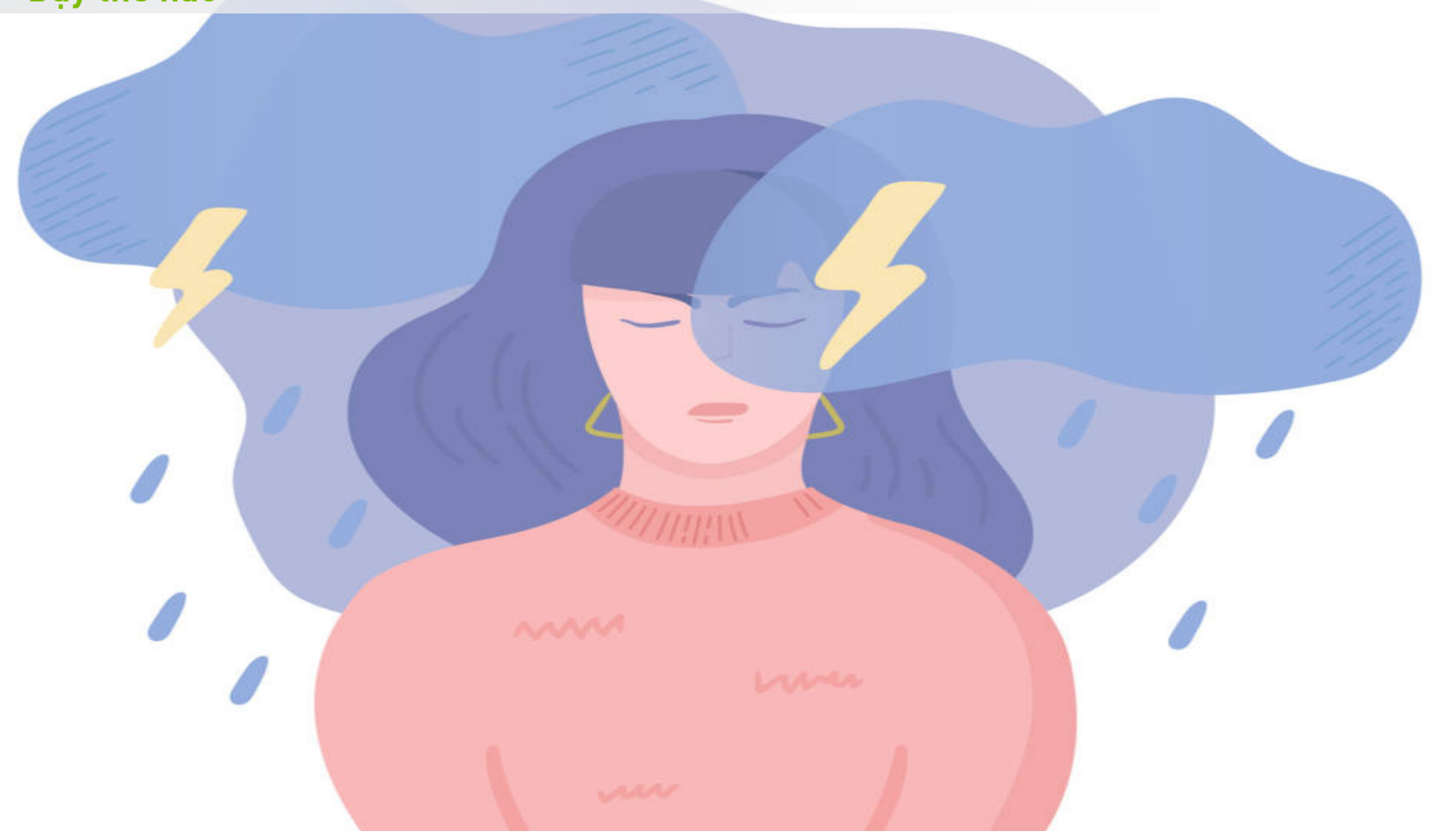

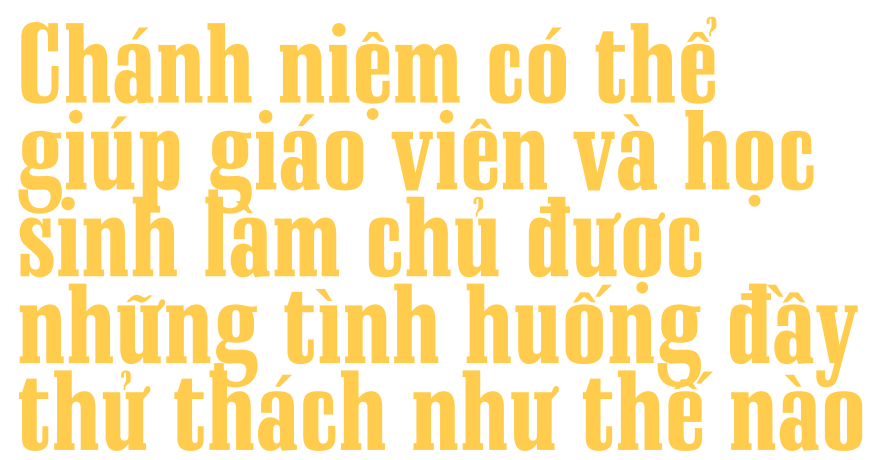

Patricia C. Broderickำ | Cẩm Khương dịch

\section{Khéo léo phản ứng: Ứng phó với thử thách trong chánh niệm}

Chánh niệm, tức là sự tỉnh thức ngay lúc này, ở đây, không phán xét, cởi mở, nghe có vẻ thư thái, tĩnh tại và cũng khá tuyệt vời. Có nhiều khoảnh khắc mời lên được sự tận hưởng trong tỉnh thức, chẳng hạn như khi chúng ta bắt đầu một kỳ nghi mà mình mong chờ từ lâu, hay khi thưởng thức một bữa ăn ngon, hoặc khi ta ghi được bàn thắng cho đội của mình. Nhưng chuyện gì sẽ xảy ra nếu

1 Tiến sĩ Patricia Broderick là một cộng sự nghiên cứu tại Trung tâm Nghiên cứu Phòng ngừa Bang Penn. Cô là một nhà tâm lý học được cấp phép, nhà tâm lý học đường được chứng nhận, cố vấn học đường được chứng nhận và là tác giả của một chương trinh giảng dạy về chánh niệm. Cô là tác giả của "Chánh niệm trong lớp học trung học: Hướng dẫn giảng dạy cho thanh thiếu niên." như ta không thực sự muốn ở trong thời khắc cụ thể này? Đối với hầu hết giáo viên và học sinh thì đó là một trải nghiệm mà chúng ta đã biết quá rõ. Hãy thử tưởng tượng lúc này là khoảnh khắc mà một vị phụ huynh đang thách thức bạn ngay trong buổi họp hay thời khắc bạn biết được một đồng nghiệp bị chẩn đoán mắc bệnh hiểm nghèo. Đối với các em học sinh thì lúc này là thời điểm em ấy mắc lỗi trong lớp, làm điều gì đó khó xử trước mặt bạn bè, hoặc phát hiện ra mình bị bỏ rơi trong một buổi tụ tập với bạn bè. Những ví dụ này là minh chứng cho phạm vi trải nghiệm đa dạng của con người. Phần nhiều trải nghiệm hàng ngày của chúng ta thường ít mang tính cảm xúc hơn nhưng để cho đơn giản thì chúng ta hãy cùng xem xét những ví dụ trên.

Một kỳ nghi, một bữa ăn ngon hay một chiến thắng rất dễ chịu, vì thế chúng ta đối diện với những khoảnh khắc này bằng sự háo hức và hân hoan. Chúng ta có xu hướng muốn có những trải nghiệm như thế. Ứng xử với những người khó tính có thể làm chúng ta lo lắng và khiến chúng ta đặt mình vào tâm thế như đang sẵn sàng đối đầu trong cuộc họp phụ huynh. Chúng ta mất 
bình tĩnh khi nghe một tin tức xấu và viện đủ cớ để hoãn việc gọi cho đồng nghiệp bị ốm. Việc phạm lỗi trong trong lớp, biểu hiện lúng túng trước công chúng hay bị loại ra khỏi nhóm bạn đồng trang lứa cũng làm cho học sinh bực bội và có thể cảm thấy muốn trốn chạy.

Mỗi giây phút đều đi kèm với tính chất cảm xúc riêng - dễ chịu, khó chịu hoặc trung tính - ngay cả khi chúng ta không nhận thức được điều đó. Con người chúng ta đều có chung một thái độ cơ bản về những trải nghiệm, chúng ta muốn có nhiều hơn các loại cảm xúc dễ chịu và muốn bớt đi (hoặc không có) các cảm xúc khó chịu. Thực ra, "căng thẳng" là một tên gọi khác của "khó chịu”. Điều quan trọng cần lưu ý là không có lợi ích gi trong việc tìm kiếm trải nghiệm khó chịu và cũng chẳng có gì sai trong việc hưởng thụ, duy trì hay trân quý những trải nghiệm dễ chịu cả. Thực tế là việc thưởng thức trong chánh niệm những trải nghiệm tích cực có thể làm tăng trưởng tính kiên cường (Smith \& Bryant, 2006). Tuy nhiên, khi chúng ta gặp vấn đề trong việc đương đầu với những những khó khăn không tránh khỏi trong cuộc sống hoặc khi chúng ta tình nguyện tiếp sức thêm cho chính gánh nặng căng thẳng của mình thì đó là lúc chúng ta cần lấy lại cân bằng.

Do chúng ta bị thúc đẩy bởi kỳ vọng rằng mình có khả năng làm những điều khó chịu biến mất, chúng ta thường nỗ lực để quản lý sự căng thẳng hay trải nghiệm khó chịu bằng cách cố gắng sửa đổi nó. Sau một đợt ăn kiêng theo chế độ, chúng ta lại tăng cân gần như cũ và rồi lại chuyển qua một chế độ ăn kiêng khác, rồi lại khác nữa mà kết quả thì vẫn tương tự. Chúng ta dùng rượu và những chất khác để tự thư giãn và giải toả những rắc rối của bản thân bằng cách quên đi nhưng rôi lại thức giấc lúc nửa đêm với những vấn đề quay mòng mòng trong đầu. Chúng ta trở nên thường xuyên cáu bẳn và kiểm soát quá mức đối với một em học sinh quen chọc tức mình và dự đoán trước từng cử động khó chịu của em ấy.
Việc quản lý căng thẳng của chúng ta có tính chu kỳ, thể hiện bằng việc chúng ta cố cải biến những tình huống khó chịu thành những tình huống phù hợp hơn với bản thân một cách lặp đi lặp lại. Đôi khi chúng ta làm tốt chiến lược này nhưng về lâu dài thì cuối cùng chúng ta cũng phải đối mặt với những vấn đề tương tự hết lần này đến lần khác, làm bản thân mình bực dọc suốt cả quá trình.

Chúng ta thật có lý và sáng suốt khi áp dụng kỹ năng sửa chữa và giải quyết vấn đề đối với những thứ dễ dàng thay đổi được. Rõ ràng là không có lợi lộc gì trong việc vô thức chấp nhận một điều thiếu hiệu quả hay có hại đến bản thân và người khác. Đó là lý do chúng ta dạy học sinh lập kế hoạch, biện luận hay giải quyết vấn đề (Elias \& Tobias, 1996; Kendall \& Braswell, 1982). Đa phần thì những phương pháp ấy phụ thuộc vào tư duy logic và áp dụng thành công nhất đối với những vấn đề được xác định rõ ràng, với những giải pháp đã được xác định cụ thể chẳng hạn như cách học, giải toán, hay ăn uống lành mạnh. Tuy nhiên không phải vấn đề nào của giáo viên hay học sinh cũng được xác định rõ ràng (Kitchener, 1983). Một số thử thách rất thực tế trong cuộc sống hay lớp học lại là những vấn đề không được xác định rõ ràng, bị cảm xúc chi phối hay không có câu trả lời rạch ròi cụ thể. Làm thế nào để tôi ứng xử với những học trò nóng tính của mình? Làm sao tôi có thể duy trì được sự thấu hiểu đối với những phụ huynh không hợp tác? Làm sao tôi có thể duy trì được sự cân bằng trong khi tôi liên tục bị yêu cầu làm nhiều thêm? Chánh niệm mang đến cho cả giáo viên và học sinh một cách tiếp cận khác đến những vấn đề khó khăn, không rõ ràng cụ thể và cả những cảm xúc khó chịu trong cuộc sống thực tế. Điều đó bắt đầu bằng việc nhận ra rằng những cảm xúc không dễ chịu có thể chỉ là một dấu hiệu báo rằng bạn cần hành động theo một cách nào đó, nhưng chính bản thân những cảm xúc ấy không phải là vấn đề.

Có rất nhiều hành vi liều lĩnh và có xu hướng nguy 
Tiếng nói trong tâm trí bắt đầu hoạt động trở lại khi cậu nghĩ về những lời trêu chọc của lũ bạn, càng làm tăng thêm nỗi lo lắng trong nội tâm của cậu. Mỗi khi cậu đi ngang qua cái cầu thang đó là cậu lại nhớ mình nằm sõng soài trên những bậc thang. Cậu cũng chắc chắn rằng ai cũng nhớ điều đó. Quá trình nghiền ngẫm về việc sao mà cậu lại có thể vụng về như thế cứ tua đi tua lại trong vòng suy nghĩ không nguôi. Cậu cố gắng tránh né hoặc đè nén sự ngượng ngùng bằng cách đổ lỗi cho người khác và vẽ ra một kịch bản để trả thù. Cú ngã không chỉ khó chịu về mặt cảm giác vật lý trên thân mà sự khó chịu còn gia tăng thêm do cậu có những dòng suy nghĩ mang tính đánh giá. Sự thêu dệt thêm trong nội tâm làm duy trì sự khó chịu của vết thương trên cơ thể và tạo ra sự khó chịu về mặt cảm xúc. Nỗi đau có thể cảm nhận ở đầu gối nhưng nỗi khổ thì lại ở trong tâm trí. Đó là cú đúp đau khổ. Những suy nghĩ tự động và cảm xúc kích hoạt chuỗi phản ứng sinh lý có liên quan đến khả năng ứng phó với căng thẳng. Tâm trí của cậu bé liên tục vòng tua đi tua lại với nỗ lực biện minh cho trải nghiệm của mình và tránh cảm giác xấu hổ hay bất lực. Và có lẽ quan trọng nhất là những nỗ lực này phần lớn là vô tác dụng bởi vì ký ức về nỗi đau cứ trồi lên liên tục. Học sinh không phải là đối tượng duy nhất xử lý những mối đe dọa do mình tự nhận thức bằng cách tránh né những cảm giác khó chịu. Những dòng suy nghĩ tương tự lví dụ như: Lẽ ra minh không phải chịu điêu này. Mọi sự lẽ ra không nên khó khăn thếnàyl nghe có vẻ cũng quen thuộc cả với giáo viên.

Bạn có thể sẽ tự hỏi có cách nào khác không trong khi con người có thói quen cố hữu là cố gắng thay đổi hay tránh né những điều khó chịu. Có lẽ cũng không quá ngạc nhiên rằng những nhà nghiên cứu đương đại đã phát hiện ra rằng có nhiều cách tiếp cận truyền thống về hạnh phúc đã nói mãi rằng: việc tránh né những cảm xúc tiêu cực hoặc khó chịu thường không giúp ích gì, chứ chưa nói đến việc có khả năng làm được hay không (Hayes, 1994). Trong khi tránh né những suy nghĩ hay cảm xúc và cảm giác tiêu cực có thể mang lại sự thỏa mãn tức thời, thì việc tránh né thường xuyên lại dẫn đến những hệ lụy nghiêm trọng khi điêu đó trở thành phong cách ứng phó (Spinhoven, Drost, de Rooij, van Hemert, \& Penninx, 2014). Kiến thức này đặc biệt quan trọng đối với thanh thiếu niên bởi não bộ của các em vô cùng nhạy cảm với những trải nghiệm về cảm xúc và thói quen ứng phó của các em đang dần được hình thành.

Các em ở độ tuổi thanh thiếu niên cho biết, tần suất trải nghiệm những ảnh hưởng tiêu cực hàng ngày cao hơn khi các em ở giai đoạn 1018 tuổi (Larson, Moneta, Richards \& Wilson, 2002). Nhưng chính các em lại gặp nhiều khó khăn trong việc nhận diện và phân loại các cảm xúc như tức giận, buôn bã, sợ hãi, chán ghét, và bực bội hơn so với lứa tuổi trước đó, hay so với người lớn (Nook, Sasse, Lambert, McLaughlin \& Somerville, 2018). Có lẽ vậy nên việc trải nghiệm các ảnh hưởng tiêu cực ở lứa tuổi vị thành niên có liên quan đến vòng lặp cảm xúc phức tạp hơn là những cảm xúc gặp phải trong thời thơ ấu và điều đó thách thức khả năng ứng phó nhiều hơn. Như đã miêu tả trong ví dụ giả định, những chiến lược mà thanh thiếu niên thường sử dụng để ứng phó với khổ đau lví dụ như tránh né cảm xúc, đè nén cảm xúc, và suy nghĩ đi suy nghĩ lạil không phù hợp và dẫn đến nhiều vấn đề hơn về lâu dài. Mặc dù việc tránh né những trải nghiệm cảm xúc mang lại cảm giác nhẹ nhõm trước mắt nhưng có thể gây ra nhiều hậu quả lâu dài hơn như trầm cảm, lo âu, cơ hội bị hạn chế và quan hệ xã hội kém (Eastabrook, Flynn, \& Hollenstein, 2014). Chứng nghiền ngẫm hay việc tập trung liên tục vào các sự kiện, tư duy và cảm xúc tiêu cực để giảm nỗi đau trong một tình huống là nguy cơ phổ biến dẫn đến trầm cảm và lo âu ở người trẻ và người lớn (Rood, Roelofs, Bögels, Nolen-Hoeksema, \& Schouten, 2009). Một cuộc kiểm tra gần 
đây về nhiều nghiên cứu đã chỉ ra rằng những chiến lược bất hợp lý mà nhiều người trẻ đang áp dụng để quản lý những cơn đau cảm xúc của mình thực ra đóng vai trò là nguyên nhân gây ra sự phát triển của những vấn đề kéo theo sau này (Schäfer, Naumann, Holmes, Tuschen-Caffier, \& Samson, 2017). Nhiều chứng rối loạn tâm thần nghiêm trọng bắt nguồn ở lứa tuổi thiếu niên và nhiều triệu chứng rối loạn ít nghiêm trọng hơn như lo âu hay trầm cảm lại phổ biến đến mức đáng báo động (Lee et al., 2014; Spear, 2009).

Sự trưởng thành về mặt tâm lý mà nhiều giáo viên trung học phát hiện thấy ở học sinh của mình như khả năng biện luận trừu tượng hoặc hiểu được góc nhìn của người khác thì cũng có cái giá của nó. Bởi vì người trẻ có khả năng tư duy trừu tượng nên họ cũng có khả năng chìm vào dòng suy tưởng giả định (Ví dụ: Chuyện gì xảy ra nếu minh giàu hoặc gâyy như cô ây?) và có thể đi đến những kết luận phản thực tế (Ví dụ: Thì minh sẽ hạnh phúc hơn). Cũng chính những kỹ năng hiểu biết nội tâm cho phép học sinh hiểu được quan điểm của Atticus Finch trong tiểu thuyết của Harper Lee, có tên Giết Con Chim Nhại, cho phép các em tưởng tượng và ngẫm nghĩ xem bạn bè và thầy cô đang nghĩ gì về minh (Blakemore \& Mills, 2014). Truyền thông xã hội tạo điều kiện để sẵn sàng so sánh bản thân và người khác, một quá trình được gọi là so sánh xã hội. Quá trình so sánh xã hội vốn đã tăng mạnh trong giai đoạn thanh thiếu niên thì do việc sử dụng quá mức các phương tiện truyền thông lại khiến điều đó càng trở nên trầm trọng hơn và dẫn tới những triệu chứng trầm cảm (Nesi \& Prinstein, 2015). Nạn bắt nạt trực tuyến được xem là mối đe dọa đặc biệt đối với thanh thiếu niên bởi vì hành vi xấu hổ của một người mà bị phơi bày công khai, thì sẽ dẫn đến việc so sánh với người khác và xa lánh xã hội (Nilan, Burgess, Hobbs, Threadgold, \& Alexander, 2015).

Nhìn chung, mặc dù những thay đổi của thanh thiếu niên trong sự phát triển về mặt nhận thức và cảm xúc có nhiều lợi ích rõ ràng nhưng điều đó cũng làm gia tăng chứng nghiền ngẫm và đau buồn đối với một số người trè. Cũng như các nhà giáo chăm chỉ làm việc để chuẩn bị cho học sinh những kiến thức và kỹ năng học thuật cho giai đoạn tiếp theo trong cuộc đời các em, thì tương tự thế, chúng ta cũng nên chuẩn bị cho các em những kỹ năng sống khác liên quan đến việc điều tiết cảm xúc một cách lành mạnh. Tuy nhiên, chúng ta cũng không thể đánh giá quá cao tầm quan trọng của bộ kỹ năng cảm xúc xã hội này với thanh thiếu niên, lứa tuổi mà tính đa cảm tăng cao và mô hình điều chỉnh cảm xúc của một người trưởng thành chỉ mới được hợp nhất (Paus, Keshavan, \& Giedd, 2008).

\section{Chánh niệm giúp điều tiết cảm xúc như thế nào}

Sự tiến bộ chính về mặt phát triển trong giai đoạn thanh thiếu niên là việc tăng trưởng khả năng lý luận, ra quyết định, và tư duy trừu tượng. Những loại hình của quá trình nhận thức này hợp lý và lôgic, được gọi là "nhận thức lạnh" (Ví dụ: Đây là những nhân tố dẫn đến cuộc nội chiến, hoặc Đây là vài bước tôi thực hiện để chia nhỏ dự án này ral và chúng thường được dạy trong các khóa học về kỹ năng ra quyết định hay học tập (Bergmann \& Rudman, 1985). Khi tư duy và việc ra quyết định được thực hiện trong bối cảnh mang tính cảm xúc, chẳng hạn như trong một nhóm bạn, thì nhận thức có thể ít mang tính lý trí hơn. Nhận thức tạm gọi là cảm tính hay "nhận thức nóng" có thể làm biến dạng tư duy và tạo cơ sở cho nhiều hành vi mang tính bộc phát (Ví dụ: Hãy quên bài tập về nhà đi. Chúng ta cùng tiệc tùng nào!). Thật khó đối với hầu hết tất cả chúng ta, nhất là đối với thanh thiếu niên, để chế ngự những cảm xúc mạnh mà có thể tư duy một cách chín chắn và hợp lý ngay cả khi chúng ta biết điều đó tốt hơn cho minh. Em học sinh mà liên tục kiểm tra tin nhắn trong lớp có vẻ như không thể kiềm chế được việc phải xem tin nhắn của bạn mình bất chấp sự phản đối của giáo viên. Em học sinh bị ngã trên cầu thang 
có lẽ không dễ dàng buông bỏ những suy nghĩ giận dữ của mình. Trong khi nỗ lực để cảm nhận được nhiều sự dễ chịu hơn như hưng phấn, và ít cảm giác khó chịu hơn như bị loại trừ hay xấu hổ, thì thanh thiếu niên cũng có thể cư xử theo cách thiếu hiệu quả đặc biệt nếu như hành vi này cuối cùng lại trở thành thói quen khó bỏ.

Chánh niệm đi vào tận gốc rễ của những khuynh hướng này bằng cách khuyến khích việc khám phá và chấp nhận mọi cảm giác mà không phán xét. Một người có khả năng nhận biết về tư duy và cảm xúc một cách có tỉnh thức tức là không chỉ có mặt ở hiện tại và tò mò về những trải nghiệm dễ chịu mà còn đối với tất cả mọi trải nghiệm. Điều này là một chân lý khó nhưng quan trọng. Chánh niệm không phải là cảm nhận theo một cách nào đó mà là cảm nhận bất cứ điều gì tồn tại trong cuộc sống của bạn ngay lúc này để có thể sáng suốt hơn trong việc phản ứng như thế nào. Điều này có nghĩa ta phải thay đổi mối quan hệ của mình với cảm giác, đặc biệt là với những cảm giác khó chịu. Thay vì cố gắng trốn tránh ngay khi ta nhận ra chúng thì ta ghi nhận chúng và thậm chí có thể sống thuận thảo với chúng. Điều này chính là những gì mà thực hành tỉnh thức và không phản ứng hướng tới.

Một số nghiên cứu chỉ ra rằng nếu chỉ đơn giản là tập trung vào việc quan sát những suy nghĩ, cảm xúc và cảm giác trên thân thể thì không có ích lợi gì mà thậm chí còn làm tăng thêm nỗi âu lo (Ví dụ như: Ôi không, suy nghĩ lo lắng lại đến nữa rôi!l) Quan trọng hơn, đó là cách chúng ta quan sát không phán xét, với trí tò mò và không phản ứng - thì mới tăng cường khả năng điều phục cảm xúc IVí dụ: Cảm giác lo lắng trong cơ thể tôi hiện giờ đang ở đâu? Tôi có thể tò mò về nó không? Tôi có thể đơn giản chi quan sát những suy nghĩ lo lắng đến và đi không?) (Baer et al., 2008; Desrosiers, Curtiss, Vine, \& Klemanski, 2014).

Quá trình quan sát cảm xúc và suy nghĩ một cách không có phản ứng cho chúng ta cái nhìn khái quát về cách tâm trí mình vận hành. Thay vị bị kẹt vào vai diễn chính trong vở kịch nội tâm của bản thân thì chúng ta chỉ ngồi ở hàng ghế đầu và xem vở kịch đó. Điều này cho phép chúng ta có góc nhìn rộng hơn và hiểu biết sâu sắc hơn. Nó cũng làm dịu đi nỗi sợ hãi mà chúng ta thường có về cảm giác của chính mình bởi chúng ta sẽ bớt việc tự động tránh né. Nếu chúng ta đang tránh điều gì đó, chúng ta cũng nhận thấy điều đó, nhưng không bình luận, không phán xét. Cảm xúc trở nên dễ chịu hơn bởi vì chúng ta can đảm để cảm nhận chúng, và từ góc nhìn mới của chúng ta, chúng ta có thể thấy rằng chúng đến rồi đi. Chúng ta có ít áp lực phải sửa đổi chúng. đồng thời có khả năng chấp nhận những trải nghiệm cơ bản của con người hơn.

Việc bình tâm quan sát và ghi nhận cả trải nghiệm dễ chịu lẫn khó chịu sẽ dễ dàng thực hiện hơn khi ta tập trung vào hơ thở hay vào một vài hoạt động cụ thể như ăn uống. Đây là lý do tại sao giáo viên thường bắt đầu từ đó. Lửa chỉ có thể thử vàng thật sự khi đối diện với căng thẳng. Nhì chung, lối thoát để chúng ta giảm phản ứng và bớt căng thẳng nằm ở chỗ ta dành tình yêu thương khi ghi nhận những cảm xúc khó chịu hay khi nhìn cách mà chúng ta thông thường vẫn dùng để đối trị với chúng (Ví dụ như tự phê phán bản thân một cách gay gắt, đả kích, suy nghĩ thái quá, buôn chuyện, bắt nạt, tự làm hại bản thân). Chúng ta chú ý những trải nghiệm về cảm xúc hay nội tâm và tốt nhất có thể thì chúng ta cứ để nguyên nó như vậy. Việc thực tập này có tác dụng khá thú vị: nó làm chúng ta thoát khỏi việc cố giải quyết vấn đề về cảm xúc khó chịu. Chúng ta bớt vật lộn và căng thẳng hơn. Chúng ta tìm ra những cách giải quyết các vấn đề khó khăn, không rõ ràng một cách ít phản ứng và tự chủ hơn. Nói một cách ẩn dụ thì chúng ta rút phích cắm để ngưng không cho dòng điện căng thẳng hoạt động. 
Phương pháp chánh niệm để tiếp cận với những thử thách

Chúng ta biết rằng, ở mức độ sâu xa nào đó thì cảm nhận được sự sợ hãi, tức giận, xấu hổ, bực bội, lo lắng và buồn bã vẫn tốt hơn là che đậy nó.

Nhưng vì đó không phải là điều chúng ta thường làm nên chúng ta cần phải luyện tập. Bạn có thể thử thí nghiệm thực hành chánh niệm khi lần tới bạn gặp điều gì đó khó chịu (tức là căng thẳng). Có thể con bạn cáu kỉnh trước giờ học và bạn phải vội vàng đi làm. Khó chịu. Có thể một người đáng lẽ sẽ giúp bạn thực hiện một dự án thì lại không xuất hiện. Khó chịu. Có thể cơn đau lưng của bạn trở lại hoặc một học sinh quậy phá trong lớp của bạn và bạn không thể hoàn thành bài giảng của mình. Khó chịu. Chúng ta không thể thoát khỏi mọi căng thẳng, nhưng chúng ta không cần phải làm cho nó tôi tệ hơn. Hãy nhớ rằng không ai ủng hộ việc chúng ta cố tình làm cho bản thân khó chịu hoặc tìm kiếm những trải nghiệm khó chịu để chuốc thêm đau khổ. Có rất nhiều sự kiện xảy ra tự nhiên trong ngày không theo ý mình. Chì cần nhận diện những ảnh hưởng mà trải nghiệm mang lại cho chúng ta (tức là dễ chịu, khó chịu hoặc trung tính) và những cảm giác trên cơ thể, suy nghĩ và cảm xúc kèm theo sẽ cho ta thêm một góc nhìn khác cho trải nghiệm, xây dựng tính kiên cường và bền chí (Duckworth, 2016). Sự kiên cường về mặt cảm xúc này có thể bảo vệ thanh thiếu niên khỏi bị choáng ngợp bởi cảm xúc mạnh như tức giận, buồn bã hoặc những cảm xúc đau khổ khác mà có thể dẫn đến những hành động tai hại.

Giáo viên là những người chăm sóc tự nhiên có bản năng hướng tới việc làm cho mọi thứ tốt hơn, vì vậy, chánh niệm vào thói quen tránh né cảm giác khó chịu của bản thân cũng là một điểm khởi đầu tốt. Khi nói đến cảm xúc, không phải mọi thứ đều có thể sửa đổi hoặc khiến chúng trở nên dễ chịu và chúng ta không thể sử dụng tư duy dựa trên hiệu suất thực hiện cho các vấn đề cảm xúc. Nhiều thanh thiếu niên đã bắt đầu tin rằng chỉ có những cảm xúc dễ chịu mới được chấp nhận và những cảm xúc không thoải mái là dấu hiệu của sự yếu kém cá nhân hoặc thiếu năng lực trong cuộc sống. Sự lầm tưởng này cho thấy một gánh nặng tinh thần lớn nhưng vẫn có thể tránh được. Điều tối quan trọng là học sinh phải học cách nhận ra cảm giác không thoải mái của mình tại thời điểm này và hiểu rằng các em không cần phải thích những cảm giác này nếu các em kiểm soát nỗi muộn phiền của mình một cách cân bằng và lành mạnh.

Giáo viên có thể làm mẫu cho sự cân bằng cảm xúc để giúp học sinh hiểu rõ xu hướng che đậy cảm giác khó chịu của bản thân mình. Ví dụ, giáo viên có thể phản hồi với học sinh khi các em gặp áp lực hoặc phàn nàn về bài tập ở trường bằng cách thừa nhận sự không hài lòng với điều đó một cách rõ ràng mà không tỏ ra mình đang muốn sửa đổi hoặc đối đầu với các em. Cũng có thể, khi có điều gì đó rõ ràng đang gây căng thẳng trong lớp học, hãy nhìn nhận nó một cách cởi mở, không phán xét và tại thời điểm đó, cũng là cách làm mẫu cho học sinh phương pháp thực hành chánh niệm đối với những hoàn cảnh khó chịu. Các bài thực tập trong chương này có thể cung cấp nền tảng cho kỹ năng cảm xúc này.

Đôi khi áp lực về thời gian hoặc yêu cầu về thành quả, sự mệt mỏi, bồn chồn và chán nản bị tích tụ trong lớp học khiến học sinh phản ứng theo những cách tiêu cực. Nếu chỉ đơn thuần là tránh né sự hiển nhiên của hoàn cảnh bằng cách cứ tiếp tục cố chấp sẽ khiến vấn đề trở nên tôi tệ hơn. Cho phép các em học sinh thở một vài hơi thở chánh niệm hoặc cho các em tham gia vận động có thể chứng tỏ bạn ghi nhận tình huống (Ví dụ: Tôi biết chúng ta đã làm việc chăm chỉ và các em đang cảm thấy mệt mỏi.) và cung cấp các công cụ để kiểm soát căng thẳng. Nhận biết đơn giản về cơ thể và cảm nhận các cảm giác của nó (Ví dụ: Chú ý tới đôi chân trên sàn, căng thẳng ở vail mà không cần thay đổi bất cứ điều gì có 
thể là một liều thuốc giải đặc biệt hiệu quả cho căng thẳng. Nhận thức về cơ thể hay cảm nhận nội thân (interoception) giúp học sinh điều chỉnh căng thẳng của các em bởi nó tạo sự chú ý tới cơ thể và hạn chế sự khuếch đại nỗi đau khổ do các luồng suy nghĩ xoắn ốc và phản ứng cảm xúc gây ra (Roeser \& Pinela, 2014).

Mặc dù "góc bình an" trong lớp học hoặc những nơi học sinh có thể đến để tự điều chỉnh bản thân đang trở nên phổ biến hơn đối với trẻ nhỏ (Lantieri, 2002) nhưng những nơi này lại thường không dành cho thanh thiếu niên. Mục đích của góc bình an trong lớp học là cung cấp cho học sinh một nơi an toàn để các em có cơ hội đối trị những cảm xúc mạnh mẽ bằng cách nhận ra chúng, chấp nhận chúng và khôi phục sự cân bằng. Sau đó, các em có thể tìm ra biện pháp mang tính trách nhiệm để hành động mà không làm tổn thương bản thân hoặc người khác. Cơ hội tự nguyện nghỉ ngơi để khôi phục khả năng kiểm soát cảm xúc chắc chắn là điều mà thanh thiếu niên cần. Dạy cho các em một số cách thức không mang tính kỷ luật để thực hiện điều này trong môi trường giáo dục trung học có thể giúp thanh thiếu niên phát triển khả năng tự điều chỉnh tốt hơn và cuối cùng là cải thiện được việc học tập.

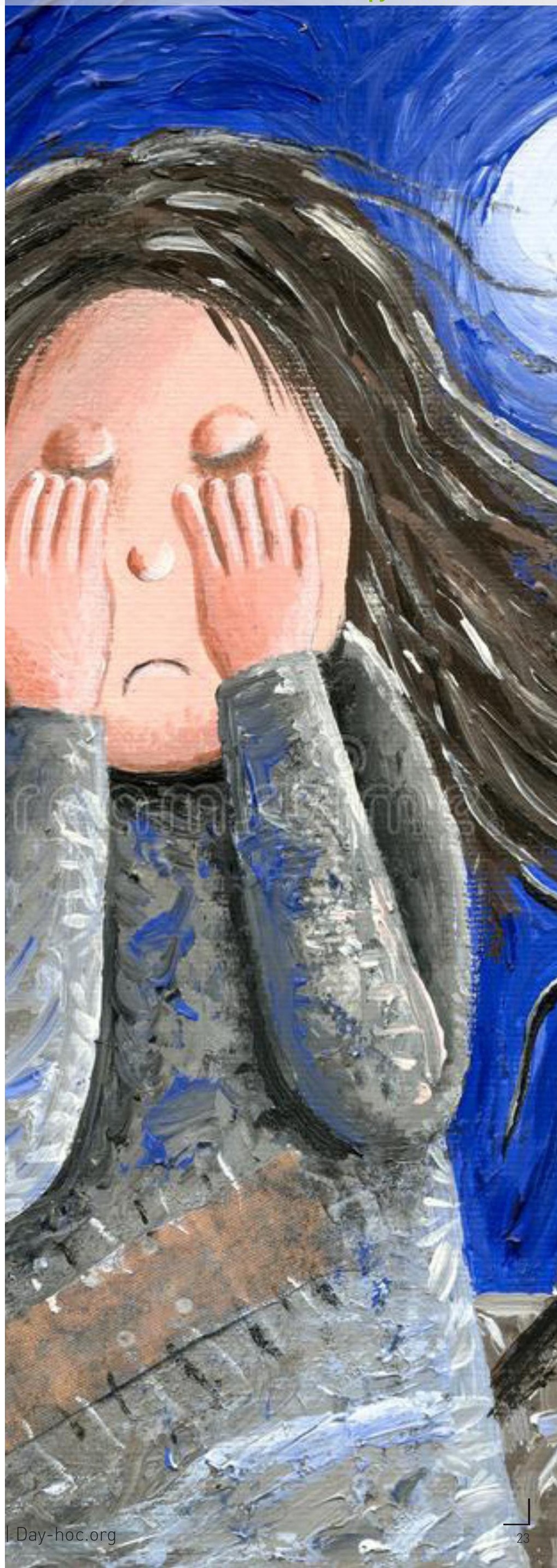




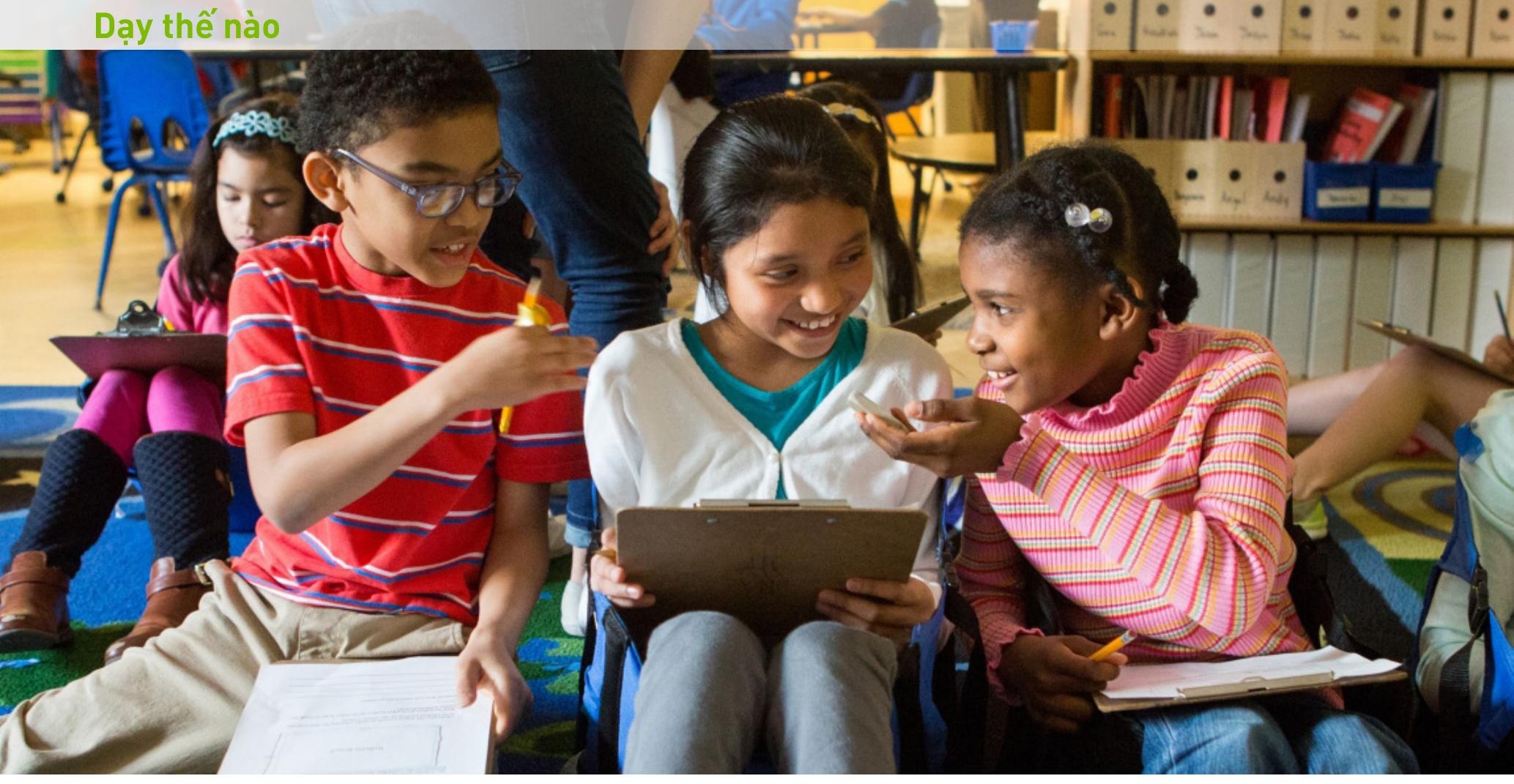

\section{CHUYÊN SANG DẠY HỌC DẢO NGƯỚC}

${ }^{1}$ Cathy L.Seeley I Ngô Trọng Đại dịch

Học sinh học được nhiều hơn khi chúng ta để cho các em tự “ đánh vật" với một bài toán trước khi chúng ta dạy học sinh cách giải.

Ở thế kỷ 20, tôi được đào tạo cách dạy toán học giống như cách mà tôi đã được học. Tôi và các bạn giáo sinh thực tập khác được yêu cầu chuẩn bị bài học kỹ lưỡng, phải trình bày khái niệm hay quy trình dự kiến một cách rõ ràng (tất nhiên, cùng với cả sư nhiệt tình), và hướng dẫn học sinh 1 Nguồn: http://www.ascd.org/publications/educational-leadership/oct17/vol75/num02/Turning-Teaching-Upside-Down.aspx qua các ví dụ. Cuối cùng, chúng tôi giao bài tập về nhà, bao gồm một số bài toán trong đó học sinh sẽ áp dụng quy trình vừa học. Chúng tôi hy vọng học sinh sẽ đặt ra câu hỏi nếu các em không hiểu.

Cách tôi học để dạy toán không khác nhiều so với cách của các giáo viên dạy các môn khác. Những năm sau đó,chúng tôi bắt đầu nhận ra rằng việc cung cấp thông tin một chiêuu này có thể biến học sinh thành nạn nhân của sự bực bội và thất bại, đặc biệt là khi các em phải đối mặt với những vấn đề khó khăn mà không được dạy cách xử lý. Nếu chúng ta chỉ dạy học sinh bằng cách cung cấp

\begin{tabular}{|c|c|}
\hline Dạy học truyền thống & Dạy học đảo ngược \\
\hline $\begin{array}{l}\text { - Giáo viên giải thích định nghĩa hoặc khái } \\
\text { niệm. } \\
\text { - Học sinh và giáo viên cùng nhau làm ví dụ. } \\
\text { - Học sinh ap dụng kiến thức đã học vào giải } \\
\text { bài toán. }\end{array}$ & $\begin{array}{l}\text { - Học sinh giải quyết vấn đề mà chưa từng } \\
\text { gặp trước đó. } \\
\text { - Học sinh và giáo viên thảo luận về suy nghĩ } \\
\text { và cách làm của học sinh. } \\
\text { - Giáo viên giúp kết nối cuộc thảo luận trong } \\
\text { lớp với mục tiêu bài học. }\end{array}$ \\
\hline
\end{tabular}

Hình 1. Dạy học truyê̂n thống và dạy học đảo ngược 
cho các em những quy trình cụ thể để giải quyết các vấn đề có thể dự đoán được, thì học sinh sẽ làm thế nào để học cách đối phó với những vấn đề trông không giống với những gì ở cuối chương sách?

Một mô hình mà tôi gọi là dạy học đảo ngược có thể giúp học sinh chuẩn bị tốt hơn để trở thành những người giải quyết vấn đề linh hoạt và mạnh mẽ. Trong mô hình này (xem hình 1), giáo viên chỉ giao bài tập sau khi đã dạy cho học sinh cách giải. Thay vào đó, dạy học đảo ngược bắt đâu với một vấn đề hoặc nhiệm vụ mà học sinh có thể chưa biết cách giải quyết (Seeley, 2014;2016).

\section{Nỗ lực để đạt mục đích}

Trong quá khứ, nhiều người trong chúng ta đã cố gắng bảo vệ học sinh của minh khỏi thất bại, đặc biệt là trong lớp học toán. Kết quả là nhiều thế hệ học sinh đã học cách từ bỏ mỗi khi bài tập trở nên khó nhằn. Nhưng hóa ra "vật lộn" một cách có tính xây dựng với các khái niệm toán học có thể thu hút suy nghĩ của học sinh và giúp các em học được tính kiên trì khi giải quyết vấn đề (Hội đồng giáo viên Toán học quốc gia, 2014). Từ nghiên cứu về tư duy phát triển của Carol Dweck (2007), chúng ta biết rằng não bộ con người phát triển khi người đó đấu tranh một cách hiệu quả với những vấn đề khó, ví dụ như giải một bài toán đầy thử thách (Boaler, 2015).

Ngày càng có nhiều giáo viên xác nhận rằng học sinh có thể hưởng lợi từ việc nỗ lực giải quyết những vấn đề mà các em chưa được dạy cho cách giải quyết cụ thể. Trong quá trình này, học sinh được học về sức mạnh của nỗ lực và sự bền bi, trở thành những người giải quyết vấn đề tự tin hơn và thậm chí phát triển trí thông minh của minh.

\section{Dạy học đảo ngược bằng hành động.}

Không giống lớp học truyền thống lấy giáo viên làm trung tâm dựa trên bài giảng, lớp học đảo ngược được điều phối bởi giáo viên nhưng tập trung vào tư duy của học sinh. Mục tiêu của bài học không chỉ đơn giản là học sinh giải được một bài toán, mà còn để học sinh học những mục đích toán học của bài học bằng cách sử dụng vấn đề làm nền tảng để suy nghĩ và thảo luận. Sau khi chọn một vấn đề để bắt đâu bài học, giáo viên trở thành người điều phối cuộc thảo luận của lớp học - làm thế nào để học sinh chia sẻ suy nghĩ của mình theo những cách mà dẫn đến kết quả bài học và giúp học sinh liên kết cuộc thảo luận với mục tiêu toán học. Khi giáo viên đi vòng quanh lớp, cô ây thường đưa ra những câu hỏi để giúp học sinh làm rõ suy nghĩ của mình hoặc hiểu sâu hơn. Trong lúc này, giáo viên cũng dần đưa ra quyết định về việc học sinh sẽ trình bày với cả lớp điều gì và các em sẽ được gọi lên theo thứ tự nào.

Thinh thoảng, cuộc thảo luận của học sinh sẽ đem đến kết quả trực tiếp mà giáo viên mong muốn như trong bài học lớp 2 liên quan đến phép trừ mà tôi sẽ trình bày rõ hơn trong bài viết này. Với những trường hợp khác, có lẽ giáo viên cần phải điều hướng cuộc thảo luận một cách trực tiếp hơn, đi thẳng vào kết quả môn học. Trong cả hai trường hợp, học sinh sẽ tham gia vào việc suy nghĩ về vấn đề và do đó, các em có nhiều khả năng học được nhiều về toán học hơn so với việc được chỉ dẫn phải làm gì.

Hãy cùng xét bốn ví dụ minh họa cho khái niệm đảo ngược và chứng minh được sự đa dạng các nhiệm vụ mà giáo viên có thể chọn để bắt đầu bài học đảo ngược.

\section{Bắt đầu với một hình ành hoặc video hấp dẫn: Có bao nhiêu cái bánh quy?}

Trong một bài học ở lớp 2, học sinh xem một đoạn video về một bàn tay đây lông vươn lên sau quầy bếp và lấy đi một gói bánh quy chưa mở. Sau vài âm thanh nhai và lạch cạch, bàn tay đặt gói bánh trở lại quây với một ít bánh quy đã biến mất. Sau đó, giáo viên hỏi “Các em chú ý thấy 
điều gì trong video đó? Các em thắc mắc điều gì?" Các học sinh trình bày quan sát của họ và giáo viên giúp họ tập trung vào câu hỏi mà họ cần giải quyết: Con quái vật đã ăn bao nhiêu cái bánh quy?

Sau đó học sinh làm việc theo cặp để giải bài toán. Khi giáo viên di chuyển xung quanh các cặp, cô nhận thấy rằng các học sinh đã tiếp cận vấn đề theo những cách khác nhau. Một trong những vai trò quan trọng của giáo viên trong hình thức giảng dạy này là quyết định cô sẽ gọi ai trong suốt cuộc thảo luận của cả lớp và học sinh nên trình bày bài của mình theo trình tự nào để làm nổi bật các cách tiếp cận khác nhau. Kết thúc bài học, giáo viên có thể viết lên bảng một bản tóm tắt rõ ràng về bài làm của học sinh, giúp học sinh hiểu rằng phép trừ có thể là kết quả của dấu trừ hoặc hiệu, giúp học sinh nhận thấy rằng kết quả ở hai vế có liên quan với nhau.

Thiết lập bài học này dựa trên mô hình Bài học ba hành động của Dan Meyer (2011). Xem video đã chỉnh sửa của bài học này tại Teaching Channel. https://www.teachingchannel.com/blog/modeling-with-mathematics

\section{Bắt đầu với các ví dụ thực tế: Điều gi xảy ra nếu thay lốp xe lớn hơn?}

Những bài toán có ứng dụng trong cuộc sống hàng ngày có khả năng thu hút sự quan tâm của học sinh. Ví dụ, trong bài học lý luận định lượng lớp 12 được trình bày trong video clip này². Giáo viên mang vào một chiếc lốp xe lphụ tùng ô tô của cô âyl. Cô đặt nó trên sàn và yêu cầu học sinh ghi lại các con số trên lốp xe và thảo luận về những con số đó thể hiện điều gì về các thông số của lốp xe. Sau đó, cô yêu câu học sinh của mình xem xét điều gì sẽ xảy ra nếu ai đó thay lốp xe này bằng lốp xe lớn hơn.

2 https://www.youtube.com/watch?v=kNNMG7Wh9eU\&feature=youtube Bài giảng và video này thuộc về Advanced Quantitative Reasoning, một khóa học được phát triển bởi Texas Association of Supervisors of Mathematics đồng hành với Trung tâm Charles A. Dana tại trường đại học University of Texas, Austin.
Lớp học đưa ra các ý tưởng, suy đoán rằng kích thước lốp xe sẽ ảnh hưởng đến tốc độ chạy xe, khả năng tiết kiệm xăng, độ chính xác của đông hồ đo lường, liệu chiếc xe sẽ chiếm nhiều chỗ hơn trên đường hoặc trong một điểm đỗ xe,... Cuối cùng, giáo viên thu hẹp nội dung cuộc thảo luận cho học sinh là quyết định điều tra về ảnh hưởng của việc tiết kiệm xăng nếu kích thước lốp xe thay đổi. Cô chọn câu hỏi này để học sinh có thể hiểu sâu hơn về tỉ lệ thuận khi học cách sử dụng mô hình toán học trong các bài toán không xác định. Sau đó, cô di chuyển quanh các nhóm khi học sinh giải quyết vấn đề theo cách tương tự như giáo viên lớp 2 trong ví dụ "Có bao nhiêu bánh quy" và trọng điểm của bài học là học sinh trình bày kết quả của mình cho cả nhóm.

\section{Bắt đầu với một vấn đề cơ bản: Làm thế nào để tạo ra sơn màu tím hoàn hào?}

Một giáo viên lớp 6 giới thiệu khái niệm tỉ số bằng cách trình bày một bài toán khá đơn giản. Cô cho học sinh thấy rằng cô có thể đạt được sắc thái hoàn hảo của màu sơn tím bằng cách trộn 2 cốc sơn xanh da trời với 3 cốc sơn đỏ. Sau đó, cô yêu cầu học sinh tìm hiểu cần bao nhiêu cốc sơn đỏ và sơn xanh da trời để tạo ra 20 cốc sơn màu tím hoàn hảo bằng cách tiến hành trên những hình khối lập phương và các bảng vẽ mẫu.

Khi học sinh làm việc theo nhóm nhỏ để đưa ra hình ảnh và mô hình, giáo viên di chuyển xung quanh lớp, xem quá trình như thế nào và đặt câu hỏi để thúc đẩy tư duy của các em. Nếu một nhóm đưa ra ba giải pháp khác nhau, giáo viên nhắc học sinh cần đạt được sự đồng thuận của cả nhóm. Thay vì hướng dẫn học sinh câu trá lời đúng, cô ấy nói với các em ây rằng cô ây sẽ quay lại sau vài phút để xem các em đã thống nhất ý kiến nào. Bằng cách này, học sinh có được kinh nghiệm trong việc giải thích ý tưởng của chính minh và lắng nghe ý kiến của người khác. Bạn có thể xem video đã chỉnh sửa một phần của bài 
học này ${ }^{3}$.

\section{Bắt đầu với một sai lầm: Tọa độ có chính xác không?}

Một giáo viên dạy toán trung học phổ thông đặt một đồ thị lên bảng với một số tọa độ được dán nhãn bằng hai màu khác nhau. Giáo viên cho học sinh biết có thể có lỗi trong các tọa độ được hiển thị bằng màu đó. Học sinh làm việc theo cặp để thảo luận về đề bài trên, xem xét xem có sai sót nào không và xác định các trường hợp giải của nhóm mình và trình bày cho các thành viên còn lại của lớp. Sau đó, giáo viên cho cả lớp thảo luận thành nhóm lớn, trong đó học sinh trình bày suy nghĩ của mình với các bạn, cuối cùng đi đến thống nhất về giải pháp đúng ${ }^{4}$.

\section{Chúng ta có thể học được gì từ những lớp học đảo ngược này}

Đoạn trích video ngắn đã được chỉnh sửa về các lớp học như thế này có thể không hiển thị tất cả các yếu tố của một bài học đảo ngược. Ví dụ, trong một số bài học đầy đủ có trích dẫn trong video clip trên, chúng ta có thể thấy rằng giáo viên đã giúp học sinh tổng kết kết luận toán học ở cuối bài học. Tuy nhiên, những gì chúng ta có thể nhận thấy qua các ví dụ này là các loại nhiệm vụ mà giáo viên đã chọn và cách giáo viên xây dựng bài giảng trong lớp.

Trong mỗi lớp học này, giáo viên chuẩn bị cho cả nhóm xây dựng nhiệm vụ hoặc tạo điều kiện cho học sinh hình thành câu hỏi mà các em sẽ cố gắng trả lời. Tất cả bốn loại nhiệm vụ được sử dụng trong các ví dụ này có thể dễ dàng được điều chỉnh cho phù hợp với bất kỳ lớp nào và cũng có nhiều loại vấn đề hoặc nhiệm vụ khác cũng sẽ phù hợp cho các bài học đảo ngược. Khi lựa chọn nhiệm vụ cho các bài học như vậy, giáo viên cần

3 Từ lllustrative Mathematics (Toán học Minh họa), Smarter Balanced Assessment Consortium and Teaching Channel: https://learn.teachingchannel.com/video/ratios-and-proportions-lesson-sbac

4 Bạn có thể xem video đã chỉnh sửa của bài học này từ PBS Learning Media: http://mass. pbslearningmedia.org/resource/mtc13.pd.math.deb/encouraging-debate tìm kiếm các nhiệm vụ “có tính phân hóa”. Tức là tìm kiếm các nhiệm vụ có mức độ năng lực đa dạng để về cơ bản thì tất cả học sinh đều có thể tiếp cận nhiệm vụ ở một mức độ nào đó và cũng cho phép học sinh mở rộng hoặc đào sâu thêm (Smith \& Stein, 2011).

Về cách điều phối bài giảng, giáo viên trong các lớp học đảo ngược di chuyển xung quanh học sinh khi họ làm việc, đặt câu hỏi hoặc đưa ra nhận xét như “Thầy/cô nhận thấy rằng nhóm của các em có ba kết luận khác nhau. Thây/cô sẽ quay lại sau vài phút để xem các em đã đồng ý về kết luận mà các em muốn trình bày trước lớp hay chưa” hoặc “Em có thể vẽ lên giấy ý tưởng mà em vừa chia sẻ không? "hoặc "Làm thế nào mà em lại quyết định chia cho 7?". Khi giáo viên tập hợp học sinh lại với nhau sau khi làm việc nhóm, học sinh trình bày những phát hiện và giải pháp của mình trước cả lớp, giáo viên đặt những câu hỏi làm rõ, tạo điều kiện thuận lợi cho việc thảo luận thêm, và cuối cùng, làm rõ mối liên hệ toán học giữa mục tiêu của học sinh và mục tiêu toán học của bài học.

Chúng tôi cũng thấy rằng đôi khi học sinh trong những lớp học này chia sẻ các câu trả lời hoặc cách tiếp cận không chính xác. Các giáo viên đã học được rằng những cuộc thảo luận có giá trị trong lớp học có thể bắt nguồn từ những câu trả lời sai. Jo Boaler (2015) gợi ý rằng thực ra, chúng ta học được nhiều điều từ việc mắc lỗi hơn là nhận được một câu trả lời đúng. Phương pháp dạy học đảo ngược giúp cả học sinh và giáo viên hiểu rằng sai lầm sẽ xảy ra và một khi chúng xảy ra, cả lớp sẽ sử dụng cơ hội này để đào sâu vào chính suy nghĩ khiến chúng ta mắc phải sai lầm, dẫn đến hiểu biết sâu hơn về toán học. Nhờ đó, khả năng học sinh có thể sử dụng những gì đã học để giải quyết các vấn đề khác trong tương lai sẽ tăng lên.

Giờ đây, giáo viên có quyền truy cập vào nhiều 
video công khai thể hiện cách dạy toán này, cho dù có được dán nhãn "đảo ngược", "tập trung vào vấn đê", "tập trung vào học sinh" hay chỉ là "lớp học toán". Những video được mô tả ở đây mang lại cơ hội tuyệt vời để chúng ta chiêm nghiệm độc lập hoặc thảo luận chuyên môn giữa các đồng nghiệp. Khi quan sát các lớp học trong thời gian thực hoặc phân tích video trực tuyến, các nhà giáo dục có thể đặt những câu hỏi như:

૫ Giáo viên sử dụng vấn đề hay nhiệm vụ nào để bắt đâu bài học?

u Giáo viên khuyến khích tư duy của học sinh và kích thích khả năng diễn đạt của học sinh như thế nào?

૫ Giáo viên đặt những loại câu hỏi nào?

u Bạn nhận thấy gì về vai trò của giáo viên và học sinh?

$\square$ Giáo viên sắp xếp trình tự bài thuyết trình của học sinh như thế nào?

u Làm thế nào để giáo viên kết nối cuộc thảo luận trong lớp với mục đích của bài học?

u Lớp học này giống hay khác với lớp học của bạn hoặc những lớp học mà bạn đã từng tham dự như thế nào?

Không phải tất cả các lớp học đảo ngược đều sẽ hoàn thành bài học trong một tiết học hoặc theo cùng một mô thức. Các lớp học đảo ngược hiệu quả có sự khác biệt đáng kể về cách chúng được tổ chức và cách chúng vận hành. Điểm chung của chúng là tập trung vào việc học sinh tham gia suy nghĩ về một vấn đề mà các em chưa được dạy cách giải quyết. Giáo viên tạo tiền đề cho cả lớp, đôi khi (nhưng không phải lúc nào cũng) tạo điều kiện cho học sinh thảo luận khi các em thu hẹp những gì họ sẽ khám phá trong bài học. Sau đó, học sinh thực hiện nhiệm vụ, cá nhân hoặc theo nhóm, sau khi thảo luận toàn nhóm.

Khi chúng tôi phân tích những tiết học như vậy, chúng tôi nhận thấy rằng các tiết học ây được điều phối bởi giáo viên, nhưng không lấy giáo viên làm trung tâm. Trọng tâm là học sinh đưa ra ý tưởng, giải pháp, phương pháp tiếp cận và mô hình, ngay cả khi giáo viên tạo điều kiện cho cuộc thảo luận và làm rõ các khái niệm toán học được khám phá bởi bài làm của học sinh.

\section{Xây dựng Lớp học trở thành một nơi an toàn để chia sẻ}

Khi chúng tôi xem xét các lớp học sử dụng cách tiếp cận đảo ngược để giải quyết vấn đề, chúng tôi nhận thấy các học sinh dường như khá sẵn lòng chia sẻ suy nghĩ và ý tưởng của các em. Bất kể các em đang học lớp nào, các em dường như không hề lo lắng về khả năng mắc lỗi hay có ý kiến không chính xác. Các e kỳ vọng rằng lớp toán sẽ luôn có những cuộc thảo luận cởi mở.

Sẵn sàng chấp nhận mạo hiểm để chia sẻ ý tưởng của mình không phải là chuyện dễ dàng đối với học sinh và nó không xảy ra trong một sớm một chiều, đặc biệt là đối với những học sinh lớp lớn, những em đã ngần ngại phát biểu ý kiến trên lớp học trong nhiều năm. Các giáo viên trong những ví dụ trên đã dành thời gian tìm hiểu để tạo điều kiện cho lớp học của họ có những cuộc trò chuyện cởi mở, tôn trọng. Họ đã làm việc với học sinh để tạo ra các quy tắc lớp học tích cực khuyến khích mọi học sinh tham gia - các quy tắc dựa trên sự tôn trọng và công nhận giá trị của ý kiến của mọi người (Boaler, 2015; Chapin, O’Connor, \& Anderson, 2013; Kazemi \& Hintz, 2014 J. Một văn hóa trong đó tất cả học sinh đánh giá cao sự đóng góp của mọi học sinh khác không chỉ thúc đầy việc giải quyết vấn đề mà còn đưa ra tuyên bố mạnh mẽ rằng sự công bằng được coi trọng trong các lớp học của chúng tôi.

\section{Dạy học đảo ngược mỗi ngày?}

Có thể có hoặc có thể không hợp lý khi sử dụng loại phương pháp đảo ngược, tập trung vào vấn đề, tập trung vào học sinh hàng ngày. Ý tưởng chính là ưu tiên tư duy, lý luận và giải quyết vấn đề của học sinh hàng ngày và xây dựng lớp học nơi những kết quả đó luôn được đánh giá cao. 
Một số giáo viên sử dụng phương pháp đảo ngược hàng ngày. Những giáo viên khác có thể đưa vào bài học một nội dung không thường xuyên do giáo viên hướng dẫn, hoặc trình bày một ý tưởng hoặc quan sát toán học thú vị. Dù giáo viên xây dựng bài học theo cách nào thì học sinh cũng nên mong đợi rằng một khi bước vào ngưỡng cửa lớp học toán, các em sẽ có nhiều cơ hội để nói về suy nghĩ của mình và chia sẻ về những lập luận của mình khi các em giải những bài toán khó, thú vị.

\section{Tài liệu tham khảo}

Boaler, J. (2015). Mathematical mindsets: Unleashing students' potential through creative math, inspiring messages and innovative teaching. San Francisco, CA: Jossey-Bass.

Chapin, S. H., O'Connor, C., \& Anderson, N. C. (2013). Talk moves: A teacher's guide for using classroom discussions in math (3rd ed.). Sausalito, CA: Math Solutions.

Dweck, C. (2007). Mindset: The new psychology of success. New York: Ballantine Books.

Kazemi, E., \& Hintz, A. (2014). Intentional talk:
How to structure and lead productive mathematical discussions. Portland, ME: Stenhouse Publishers.

Meyer, D. (2011). The three acts of a mathematical story. Retrieved April 27, 2017, from http:// blog.mrmeyer.com/2011/the-three-acts-of-amathematical-story/

National Council of Teachers of Mathematics. (2014). Principles to actions: Ensuring mathematical success for all. Reston, VA: National Council of Teachers of Mathematics.

Seeley, C. L. (2014). "Upside-Down Teaching” in Smarter than we think: More messages about math, teaching, and learning in the 21st century. Sausalito, CA: Math Solutions.

Seeley, C. L. (2016). Making sense of math: How to help every student become a mathematical thinker and problem solver. Alexandria, VA: ASCD.

Smith, M. S., \& Stein, M. K. (2011). 5 practices for orchestrating mathematics discussions. Reston, VA: National Council of Teachers of Mathematics. 


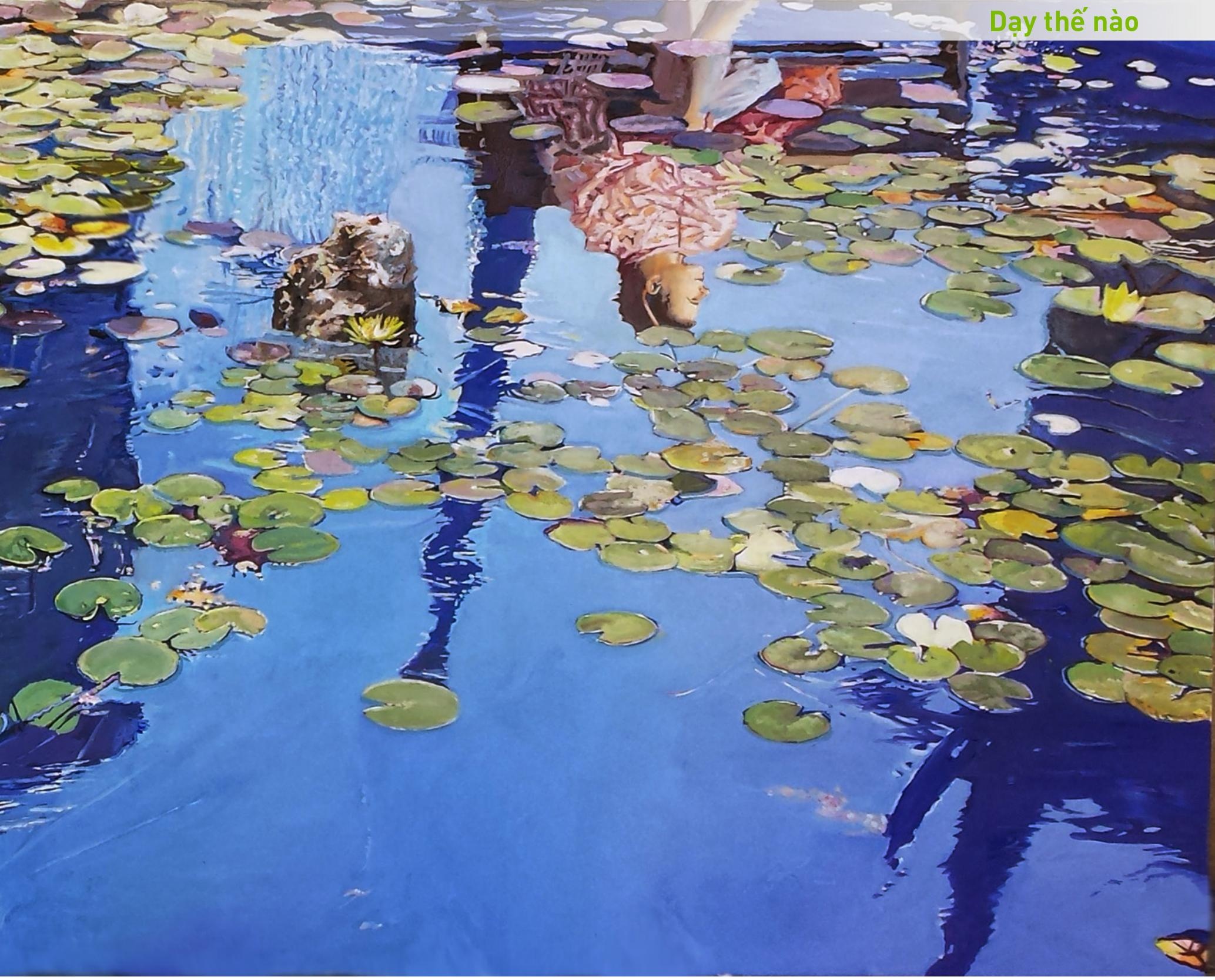

Khi chúng tới đích, chúng lại thấy rằng nước này không uống được.

Sự khan hiếm nguồn nước là 1 điều mà các học sinh hầu như sẽ không phải trải qua. Sau tất cả thì, chúng tham gia đang học ở Toronto, 1 thành phố nơi mà các con sông trong 5 lưu vực khác nhau chảy vào hồ Ontario. Chúng đang chơi tại Evergreen Brick Works - 1 nhà máy gạch cũ đã được chuyển thành trung tâm giáo dục môi trường cộng đồng. Đối với trẻ em trong 1 số cộng đồng, thậm chí là ở Canada, trò chơi này chính là thực tế đối với chúng. Sự chênh lệch là 1 trong nhiều chủ đề có phần u ám hơn trong sự giáo dục về nguồn nước.

"Khi các học sinh nhìn vào địa cầu và thấy nó màu xanh, nó có vẻ như chứa rất nhiều nước",
Cailin Hillier, điều phối viên tại Canadian Water Network cho biết. Nhưng điều đó là không đúng. Trong quá trình thuyết trình trên các lớp học, cô thỉnh thoảng sử dụng 1 lít nước để đại diện cho nguồn cung cấp nước trên thế giới. Sau đó, cô ấy loại bỏ nước mà con người không thể uống, có lẽ bởi vì nó là của đại dương, lạnh băng, hoặc quá xa dưới lòng đất để có thể tiếp cận. Khi cô ấy kết thúc, chỉ 1 giọt còn lại. Sự khan hiếm đó là có thể khiến cho ai đó chết chìm trong tuyệt vọng.

Có lẽ sự hiệu quả của H20 Zone hay các lễ hội về nước khác chính là cách mà họ biến 1 chủ đề thường bị vùi trong ngôn từ khoa học hay trong các hội thoại về ngày tận thế trở nên thú vị. Hillier coi sự tham gia lễ hội té nước của trẻ em trong trường tiểu học như 1 điều gì đó đã 
khởi dậy sự thích thú của cô ấy với chủ đề này. Các lễ hội như vậy có diễn ra trong nhiều vùng nhưng không có ở Toronto. Patti Birk - là 1 giáo viên tiểu học tại trường tiểu học Công giáo St. Joseph ở Acton, Ontario, đã đưa lớp học của cô ấy đến lễ hội té nước của trẻ em ở Halton khoảng 3 năm trước. Xấp xỉ 4000 học sinh ở lớp 2 - 5 tham gia vào lễ hội mỗi tháng 9. Các học sinh có thể chưa hình thành sự gắn kết trong lớp học nhưng việc lập kế hoạch cho 1 bài giảng tiếp theo thì không khó, Birk nói. Các học sinh luôn luôn hoàn toàn thích thú khi bài giảng kết thúc. Có rất nhiều điều để thảo luận như: những cái kính hiển vi cho phép chúng khám phá về nước theo những cách không thể có tại trường, những chú chim mà chúng được nhìn ở cự ly gần, những trò chơi tiên phong chúng chơi để xem nguồn nước đã được sử dụng như thế nào trong lịch sử, hay trò chơi được ưa thích nhất theo trải nghiệm của Birk, là cuộc đua vịt cao su để nhắc nhở chúng về vận tốc. Lễ hội cho phép các học sinh được nhìn nhận về nước "dưới nhiều lăng kính khác nhau", Birk nói.

Trong giáo dục về môi trường, nhìn có thể là điều quan trọng nhất.

"Tôi nghĩ điều duy nhất là thực sụ̣ hiệu quả là liên tục đưa (học sinh) ra ngoài (để tiếp cận trực tiếp)", Mike Klassen, hiệu trưởng Học viện Rivers Collegiate ở Rivers, Manitoba, 1 trường trung học ưu tiên về giáo dục môi trường. "Những gì chúng tôi cố gắng làm ở ngôi trường này là để hướng tới phát triển một cảm giác về nơi chốn, một cảm giác được thuộc về. Khi bạn có thể mang tới điều đó cho trẻ em ở môi trường thiên nhiên, chúng sẽ bắt đầu quan tâm... Chúng sẽ học cách yêu thương nó, và sau đó là quan tâm, và sau đó là bảo vệ nó mà không cảm thấy tội lỗi."

Đúng vậy, những học sinh của anh ấy có thể có 1 số lợi thế - bên cạnh việc có số lượng học sinh nhỏ với 150 học sinh - có thể giúp cho việc toàn trường có thể cùng tham gia trở nên dễ dàng hơn. Trường duy trì vùng đất ngập nước cho riêng mình, đó là The Rivers Wetland of Excellence, cách trường vài bước chân. Đó là 1 dự án khai hoang: địa điểm này đã từng là một đường sắt, khi ngừng sử dụng, nó được phá bỏ và trở thành 1 đầm lầy. Vùng đất ngập nước bây giờ đã được 3 năm. Ban đầu ngôi trường có kế hoạch 5 năm cho địa điểm này, nhưng Klassen nói rằng dự án có khả năng sẽ kéo dài lâu hơn.

Cho tới giờ, nó vẫn đang sống đúng với cái tên của mình - vùng đất ngập nước ngày nay đã thắng giải Bảo tồn Thanh niên từ Liên đoàn Động vật Hoang dã Canada. Lợi ích nó đem lại là vô kể, không chỉ đối với nguồn nước, thực vật và động vật, mà còn cho trường học và cộng đồng. Vùng đất ngập nước vừa là một lớp học vừa là một phòng thí nghiệm, các học sinh lớp sinh học lấy mẫu nước và tạo các danh sách về các loại thực vật và những loài động vật, các học sinh lớp chế biến gỗ thì tạo các bến tàu và lồng chim gỗ. Trường đã tạo ra những chương trình học dựa trên vùng đất ngập nước này, như là khóa Quản lý các vùng đất ngập nước, khoá này đã được khu vực đó công nhận. Các học sinh cũng tổ chức những chuyến tham quan phù hợp với chương trình giảng dạy cho các lớp tiểu học trong địa phương. Vùng đất ngập nước là 1 phần của công viên lớn mà còn bao gồm một sân đá bóng và thị trấn đang nghĩ đến việc biến nó thành 1 phần của chiến lược du lịch sinh thái, Klassen chia sẻ.

Hầu hết các trường học không có khả năng tạo ra một vùng đất ngập nước, nhưng những học sinh vẫn nên biết nơi nguồn nước chúng uống và sử dụng đến từ đâu và làm thế nào để lấy được chúng. Nhiều người không hiểu rằng các hệ thống nước khác nhau được kết nối với nhau như thế nào, Hillier nói. Nhưng ngay cả học sinh cũng có thể có những cuộc trò chuyện nghiêm túc về chủ đề này. Cô ấy đã từng giải thích các 
cách xử lý nước như thế nào với học sinh khối lớp 1 ở một thị trấn phụ thuộc vào nước ngầm. Cô ấy kể cho chúng nghe về các giếng nước, và làm thế nào clo được sử dụng để tiêu diệt vi khuẩn trong nguồn nước. Một học sinh hỏi rằng làm thế nào mà mọi người biết clo đã "thắng" lũ vi khuẩn. Hillier sau đó giải thích về clo dư- tức là nếu còn một ít clo trong nước, nó có nghĩa là clo đã thắng. "Thật sự là một câu hỏi rất ngẫu nhiên”, cô ấy nhớ lại.

Các giáo viên nên khai thác sự tò mò của học sinh - có rất nhiều phương thức phong phú để khuyến khích giáo dục về nguồn nước và bảo tồn trong trường học. Nhiều học sinh đã cảm thấy nó rất thú vị và điều này áp dụng cho nhiều môn học khác. "Học sinh hiểu rằng chúng có trách nhiệm với thế giới xung quanh chúng”, Birk - giáo viên tại EcoSchool cho biết. (Nằm ở Ontario, EcoSchool là những trường được đăng ký chính thức với chương trình Ontario EcoSchool với mục tiêu giúp giáo dục các trường học về làm thế nào để có các thực hành môi trường bền vững và làm sao để theo dõi tiến trình của chúng). "(Học sinh) hiểu rằng (môi trường là) một phần tương lai của chúng, và chúng có kết nối với nó". Điều đó có thể được nhìn thấy ở những điều nhỏ nhất. Birk nhớ lại một khoảnh khắc trong giờ ăn trưa khi các học sinh nháo nhác yêu cầu cô ấy gỡ một chiếc túi nilon bị mắc kẹt ra khỏi cái cây. Chúng lo ngại cái túi sẽ làm ô nhiễm nguồn nước gần đó, Birk kể lại.

Nuôi dưỡng ý thức quan tâm tới nguồn nước có thể khuyến khích một điều nghe chừng là phản trực quan: dùng nước máy. Nước máy được quản lý chặt chẽ hơn nước đóng chai, Hillier giải thích, điều này có nghĩa là nó an toàn hơn để uống. Nó cũng rẻ hơn. Nhưng thường thì mọi người thích uống nước đóng chai hơn, mặc dù nó đến từ những chai nhựa dùng một lần với tương lai chắc chắn sẽ là nằm trong bãi rác. Nhiều trường học đang chống lại xu hướng này bằng cách thay thế những vòi nước bằng sứ với các khu để chai nước nhựa, và khuyến khích học sinh uống từ những chai nhựa có thể tái sử dụng.

Đôi khi, việc tiết kiệm nước đưa giáo viên tới những địa điểm họ không ngờ tới. Shannon Boyle vốn đã yêu nước từ trước tới nay, và nó là một niềm đam mê cô ây mang đến cho học sinh mỗi tuần với tư cách là giáo viên phụ trách của câu lạc bộ Water Warriors, là câu lạc bộ dành riêng cho giáo dục trường học của họ về bảo vệ tài nguyên nước. Cô ấy dạy môn khoa học xã hội tại trường St. Michael, 1 trường tiểu học ở Calgary, vì vậy cô ấy ý thức được những vấn đề toàn cầu. Khoảng thời gian đào tạo các giáo viên ở Ghana đã cho cô ấy trải nghiệm việc sống chung với sự khan hiếm nước.

Nhưng có một năm, học sinh của cô ấy dẫn cô đến một nơi không thân quen với cô ấy: phòng vệ sinh nam. Chỉ có các nam sinh tham gia vào câu lạc bộ vào năm đó, và chúng quyết định trang bị thêm cho bồn tiểu cảm biến chuyển động. Trước đây, nước sẽ chảy trong bồn mỗi 20 phút. Lắp đặt những cảm biến đó có nghĩa rằng nước chỉ chảy khi được kích hoạt. "Tôi chưa bao giờ nghĩ tới bồn tiểu", Boyle thừa nhận. Boyle hoàn toàn ý thức về cách mà cô ây muốn học sinh của cô ấy nghĩ về nước. "Nhiều người muốn giảng dạy về giáo dục môi trường, nhưng họ sử dụng cách tiếp cận sai lầm", cô nói. "Họ sử dụng tiếp cận vấn đề". Thật không công bằng khi đặt gánh nặng ô nhiễm và biến đổi khí hậu đến lũ trẻ, Boyle nói. Thay vì vậy, giáo viên cần cho chúng xem cách tìm ra giải pháp trước những vấn đề choáng ngợp ấy.

Điều đó không có nghĩa là ta phải né tránh sự đấu tranh và nỗi đau. Trong suốt 2 năm vừa rồi, Boyle đã sử dụng Water Walk để giúp học sinh hiểu được khoảng cách mà một số người phải di chuyển để có thể lấy được nước. Khi thực hiện 
Water Walk, học sinh mang theo các bình sữa 4 lít và đi bộ 30 phút từ trường học đến sông Bow. Lũ trẻ đổ nước đầy vào các bình và sau đó quay về trường. Quãng đường trở lại khá là khó khăn.

"Một số thì than thơ", Boyle nói, "và tôi thích việc chúng than phiền bởi điều này nghĩa là chúng nhận ra rằng đây là 1 bài tập. Nó không phải là 1 chuyến đi chơi, là 1 sự kiện vui nhộn hay một chuyến dã ngoại ngắn. Nó là một bài tập để lấy nước." Đây là một bài tập khó khăn để tạo ra cơ hội cho sự trưởng thành. Học sinh mang những bình nước của chúng đổ đầy thùng chứa nước mưa - cái mà học sinh tiểu học dùng để tưới cây. Mọi người đều được tham gia. Điều này rất quan trọng, bởi bản thân học sinh có giá trị nhiều hơn là nguồn nước mà chúng đang bảo vệ.

"(Trẻ em là) những tâm hồn đi lạc", Klassen nói. "Chúng không biết định hướng của chúng là gì. Nếu chúng có một sự kết nối, ít nhất là đối với môi trường, chúng sẽ có thứ gì đó để kết nối, một nơ nào đó mà chúng có thể quay trở lại để dựa vào... Nếu chúng ta có thể khiến trẻ em yêu thích cộng đồng của chúng hoặc khiến chúng yêu thích môi trường ở địa phương, chúng ta sẽ thấy một sự thay đổi ở thế giới của chúng ta trong tương lai." 


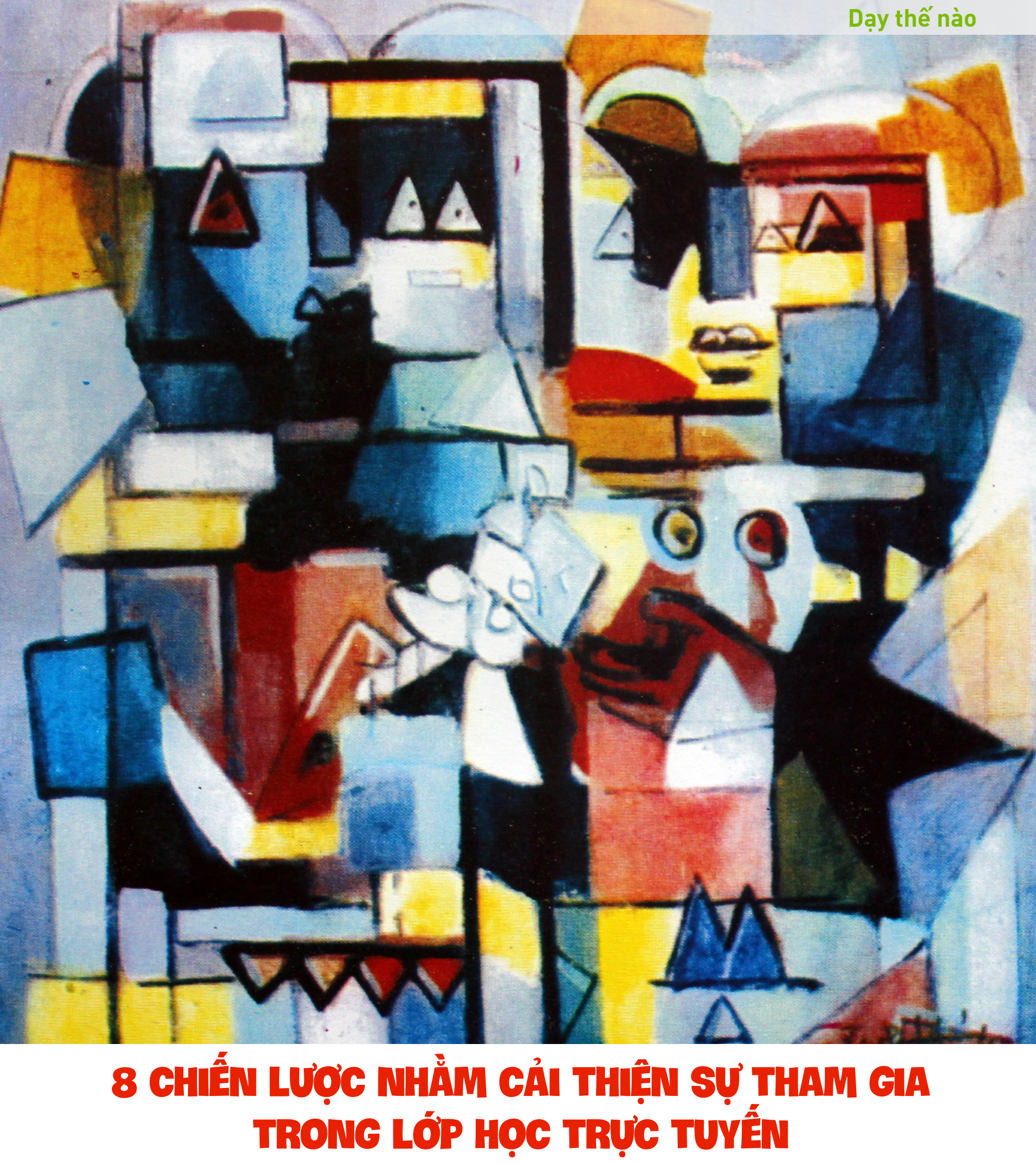

${ }^{1}$ Emelina Minero I Ngọc Lan dịch

Các nhà giáo dục chia sẻ các chiến lược đồng bộ và không đồng bộ tốt nhất của họ để thúc đẩy sự tham gia của học sinh trong quá trình học trực tuyến. 
Trong mỗi lớp học, có những học sinh luôn giơ tay để tham gia và có những học sinh còn chần chừ nhập cuộc. Cho dù chúng là người hướng nội, có xu hướng suy nghĩ một lúc trước khi đóng góp, hay chỉ là đang trải qua một ngày tồi tệ, thật khó có thể đưa những đứa trẻ vào những cuộc thảo luận mà chúng miễn cưỡng phải nói.

Những thách thức trong việc thu hút học sinh tham gia ngày càng gia tăng trong quá trình học tập từ xa, đó là ý kiến của nhiều giáo viên mà chúng tôi đã trò chuyện. Các nền tảng kỹ thuật số có thể tạo thêm rào cản giao tiếp, ví dụ như khó có thể biết khi nào nên lên tiếng hoặc làm thế nào để đọc được những chi tiết nhỏ nhưng không kém quan trọng của màn thuyết trình như ngôn ngữ cơ thể và nét mặt của một người. Ngoài ra, các cuộc thảo luận trực tuyến thường bị cản trở bởi sự không đồng đều trong khả năng tiếp cận công nghệ của học sinh và bởi những lo ngại về quyền riêng tư, và kết quả là nhiều giáo viên đã phải cho phép học sinh gửi bài qua các kênh riêng lẻ như email, điều này có thể tạo ra tương tác hai chiều ngoài luồng giữa học sinh với nhau (và giữa học sinh và giáo viên).

Hóa ra để trẻ em đóng góp vào các lớp học ảo là một công việc không dễ dàng. "Chúng tôi vẫn gọi thế hệ này là thế hệ công nghệ số bản địa như thể họ chi đơn giản là những kẻ điên cuồng với mọi thứ được máy tính hóa. Họ không như vậy". Tim O'Brien đã viết trên Facebook. "Họ cần hỗ trợ cá nhân, những bước đệm gợi ý (scaffolding) và sự yên tâm mà công nghệ không thể cung cấp. Nó chi đơn giản là một công cư, không phải là một giáo viên."

Để tìm cách cải thiện các cuộc thảo luận của học sinh và sự tham gia vào học tập trực tuyến, chúng tôi đã chọn lọc qua hàng trăm bình luận trên mạng xã hội và theo dõi hơn 20 nhà giáo dục để xem họ đã giải quyết thử thách này như thế nào vào mùa xuân năm ngoái. Các giáo viên đã đưa ra một loạt các chiến lược thông minh, cả đồng bộ và không đồng bộ, vào các lớp học mùa thu này để hòa hợp các giá trị và ý kiến của tất cả học sinh - ngay cả những trẻ trầm tính nhất hoặc những trẻ có lịch học bị gián đoạn.

\section{CHIẾN LƯợC ĐỒNG Bộ}

Đối với việc học đồng bộ, một số giáo viên cho biết họ đã chuyển từ các phương pháp thảo luận truyền thống trong lớp học sang trò chuyện video trực tiếp, trong khi những giáo viên khác nhận thấy rằng các công cụ kỹ thuật số giúp tăng cường sự tham gia lớp học.

\section{Thảo luận kiểu mạng nhện: Trong quá trình} học tập từ xa vào mùa xuân này, học sinh trong lớp trung học của Shai Klima đã dẫn dắt các cuộc thảo luận của riêng mình qua Google Meet. Trước khi diễn ra lớp học trực tiếp, học sinh phải tự trả lời các câu hỏi, sau đó chia sẻ câu trả lời của mình khi bắt đầu buổi học như một điểm khởi đầu cho một cuộc thảo luận rộng rãi hơn trong lớp.

Trong khi học sinh trò chuyện trên video, Klima đã lắng nghe và vẽ các đường thẳng trên một tờ giấy theo dõi dòng tương tác trong cuộc trò chuyện, kết quả cô nhận được một mạng lưới. Vào cuối cuộc thảo luận, Klima chia sẻ bức vẽ qua video, sau đó yêu cầu học sinh phản hồi về kinh nghiệm và những gì các em học được về người nói chuyện, người lắng nghe và người xây dựng dựa trên ý tưởng của người khác.

Klima đã chia sẻ: "Đó là một thành công trong việc giúp học sinh xây dựng môi quan hệ và giúp đỡ nhau đưa ra những ý tưởng móii."

\section{Sử dụng tính năng trò chuyện (chat) để kiểm} tra mức độ hiểu: Sau khi giảng bài vào mùa xuân năm ngoái, Paul France đã cho các học sinh lớp ba của mình sử dụng tính năng trò chuyện của Google để hỏi và trả lời các câu hỏi hoặc chọn biểu tượng cảm xúc, ví dụ như biểu tượng ngón 
trỏ giơ lên hoặc xuống, để thể hiện chúng có hiểu một khái niệm hay không. Để tạo khuôn khổ cho các câu trả lời, anh đã hướng dẫn học sinh của mình đưa ra các quy tắc xoay quanh việc sử dụng tính năng trò chuyện - ví dụ, chúng quyết định là một nhóm chỉ sử dụng một biểu tượng cảm xúc tại một thời điểm. France cho biết việc thực hành đã giúp anh kiểm tra mức độ hiểu bài của học sinh và thúc đẩy chúng gắn kết nhiều hơn vào nội dung bài học.

Trong khi đó, giáo viên mầm non Ruth Calkins đã sử dụng tính năng trò chuyện Zoom khi tổ chức các buổi học trực tiếp với học sinh mẫu giáo của mình. Cô nói rằng bọn trẻ thích gõ "T" (true) hoặc "F" (false) cho các câu hỏi đúng và sai khi trả lời các câu đố toán học trong bảng trò chuyện, và thậm chí có một số em còn cố gắng viết cả câu trả lời để đáp lại câu hỏi của cô. Đánh máy để phản hồi cũng rèn luyện rất nhiều kỹ năng thực hành bàn phím cho các học sinh nhỏ tuổi.

\section{3. Đảo ngược lớp học để kích thích cuộc thảo} luận sâu hơn: Forrest Hinton, một giáo viên toán trung học, cho biết anh đã nhận thấy rằng sự kết hợp giữa hướng dẫn đồng bộ và không đồng bộ có tác dụng tốt để kích thích học sinh thảo luận trong quá trình học từ xa.

Đầu tiên, anh dạy nội dung mới thông qua các video được ghi lại và các hoạt động trực tuyến. Khi bắt đầu lớp học trực tiếp, các học sinh đã cùng nhau tóm tắt ngắn gọn các khái niệm đã học và sau đó chia thành các nhóm nhỏ để giải quyết các vấn đề liên quan. Việc đảo ngược lớp học cho phép Hinton tốn ít thời gian giảng dạy trực tiếp hơn - và việc lắng nghe học sinh ngay từ đầu tiết học trong các nhóm nhỏ đã giúp anh xác định, và sau đó giải quyết được chỗ mà học sinh của mình còn gặp khó khăn. "Điều này cho phép tôi làm rõ các khái niệm một cách có mục tiêu hơn và hỗ trợ được học sinh tốt hơn," Hinton nói.

\section{4. Điều chỉnh phương pháp suy nghĩ-bắt cặp-} chia sẻ (think-pair-share) trong Zoom: Ryan Tahmaseb, giám đốc dịch vụ thư viện, cho biết ông nhận thấy rằng việc cung cấp nhiều hoạt động học tập dự án hơn cho học sinh tiểu học và trung học cơ sở của mình và cho phép chúng tự chủ hơn trong các bài tập, dễ dàng khuyến khích các cuộc thảo luận phong phú hơn trong lớp học thực tế. Tahmaseb nói: "Nếu chúng tôi cho học sinh càng nhiều tự do càng tốt để thử nghiệm, nghiên cứu và theo đuổi sở thích trong phạm vi nội dung chúng tôi đưa ra, thì bọn trẻ chắc chắn có nhiều điều để nói hơn."

Khi nói đến các cuộc thảo luận trong lớp, Tahmaseb đã điều chỉnh phương pháp suy nghĩ-bắt cặp-chia sẻ trong Zoom. Học sinh được nhắc nhở, chia thành các nhóm và sau đó được đưa vào các phòng riêng để thảo luận và ghi lại câu trả lời của chúng trên một file Google tài liệu đã được chia sẻ, nơi cho phép học sinh chia sẻ suy nghĩ của mình bằng cách viết hoặc đọc to. Vi Tahmaseb không có mặt ở mỗi phòng thảo luận để lắng nghe các cuộc trò chuyện, nên Google tài liệu đã làm cho học sinh có trách nhiệm hơn. Khi tất cả học sinh quay lại lớp chung, các tình nguyện viên từ mỗi nhóm chia sẻ câu trả lời của chúng với mọi người.

\section{Một bước ngoặt mới về trình bày và chia sè:}

Để học sinh thoải mái khi tham gia trực tuyến, Brittany Collins, điều phối viên dạy và học tại Write the World, một cộng đồng viết văn trực tuyến toàn cầu dành cho học sinh trung học cơ sở và trung học phổ thông, đã chuyển đổi hoạt động trình bày và chia sẻ quen thuộc thành "suy nghĩ, viết, chia sẻ".

Trong một hoạt động, Collins đã yêu cầu các học sinh trung học cơ sở và trung học phổ thông tìm một bức ảnh, bức tranh hoặc bản vẽ thể hiện sự kết nối giữa các thế hệ và tự viết ra câu trả lời cho các câu hỏi sau lấy từ cuốn sách Khung Hiển 
Thị Tư Duy trước khi thảo luận về chúng qua video với cả lớp: Chúng ta đang xem gì? Điều gì khiến bạn nói như vậy? Bạn chú ý đến điều gì Inhìn thấy, cảm thấy, biết)? Chúng ta có thể khám phá thêm điều gì? Bạn thấy ngạc nhiên về điều gì? Collins nói: "Điều này giúp phá vỡ lớp băng trong một môi trường học tập trực tuyến, nơi mà sự tham gia học tập không có kế hoạch có thể là thách thức đối với một số học sinh".

\section{CHIẾN LƯợC KHÔNG ĐÔNG Bộ}

Mặc dù một số giáo viên và học sinh nói rằng các cuộc thảo luận đồng bộ thu hút hơn vì chúng giống với một lớp học truyền thống, nhưng nhiều nhà giáo dục nhận thấy rằng các cuộc thảo luận không đồng bộ sẽ công bằng hơn vì chúng không hạn chế sự tham gia của những học sinh có băng thông thấp, những người bị giới hạn về thời gian biểu hoặc những người không thoải mái tương tác với toàn bộ lớp học.

\section{Diễn đàn trực tuyến tạo ra đối thoại qua lại:} Angelina Murphy, một giáo viên tiếng Anh trung học, cho biết cô đã sử dụng tính năng câu hỏi của Google lớp học để yêu cầu học sinh trả lời các bài đọc và lời nhắc thảo luận trong quá trình học từ xa vào mùa xuân vừa qua. Khi mỗi học sinh nhận xét, Murphy phản hồi bằng các câu hỏi làm rõ sáng tỏ vấn đề để tạo ra một cuộc đối thoại qua lại và cũng yêu cầu mỗi học sinh phản hồi ít nhất hai nhận xét của bạn mình nhằm tạo cơ sở thảo luận rộng hơn.

Giáo viên lớp 5 Raquel Linares cho biết cô đã sử dụng ứng dụng Nearpod Collaborate Itrên Apple, Android), một bảng cộng tác ảo, để yêu câu học sinh chia sẻ hình ảnh hoặc viết phản hồi để thể hiện những gì chúng đã học được về một bài báo mà chúng đọc. Để tạo tính kết nối và sự suy ngẫm giữa các bạn cùng lớp, Linares cũng đã sử dụng ứng dụng Flipgrid (trên Apple, Android), để học sinh có thể nghe thấy giọng nói của bạn bè ngay cả khi chúng đang ở cách xa nhau.

\section{Xem và phê bình sản phẩm của bạn bè thông} qua các cuộc đi dạo trong phòng trưng bày ào:

Theo Joe Marangell, một giáo viên xã hội học trung học, "các cuộc đi bộ trong phòng trưng bày" ảo cho học sinh cơ hội xem các dự án của các bạn cùng lớp để học hỏi lẫn nhau. Sau khi các học sinh của anh trình bày các dự án của riêng chúng thông qua các đoạn phim dài 5 phút, chúng được yêu cầu đưa ra phản hồi cho ít nhất hai học sinh khác về dự án của bọn tré.

Sử dụng Google Trang tính, học sinh đã đưa ra nhận xét cho bạn bè của chúng bằng cách trả lời các lời nhắc sau: Tôi học được điều gì mới về chủ đề này?; Điều gì làm tôi ngạc nhiên về chủ đề này?; Tôi thích điều gì ở bài thuyết trình này? Marangell cho biết, định dạng trực tuyến đã mang lại cho mọi học sinh cơ hội xem bài làm của bạn bè và đánh giá của bạn bè về bài của chúng để suy ngẫm một cách sâu sắc hơn.

\section{Trạm di chuyển động não trực tuyến: Khi các} hoạt động động não theo băng chuyền hoặc theo trạm được thực hiện trong môi trường lớp học truyền thống, các nhóm nhỏ học sinh sẽ xoay vòng quanh phòng đến các trạm khác nhau để trả lời các yêu cầu cũng như xem và thêm vào câu trả lời của mỗi nhóm trước đó.

Để chuyển hoạt động này sang trực tuyến, Marangell đã chia học sinh của mình thành các nhóm trực tuyến và tạo các tài liệu được chia sẻ chung trên Google-hoặc một loạt các trang trình chiếu của Google-cho các yêu cầu/câu hỏi. Mỗi nhóm để lại suy nghĩ của chúng dưới các câu hỏi theo ngày được chỉ định và sau đó theo dõi bằng cách nhận xét câu trả lời của các nhóm khác vào ngày hôm sau. Marangell nói: "Chiến lược này vẫn cho phép chúng duy trì được cảm giác ở trong một tập thể lớp học [trong bôi cảnh lớp học ảo]". 


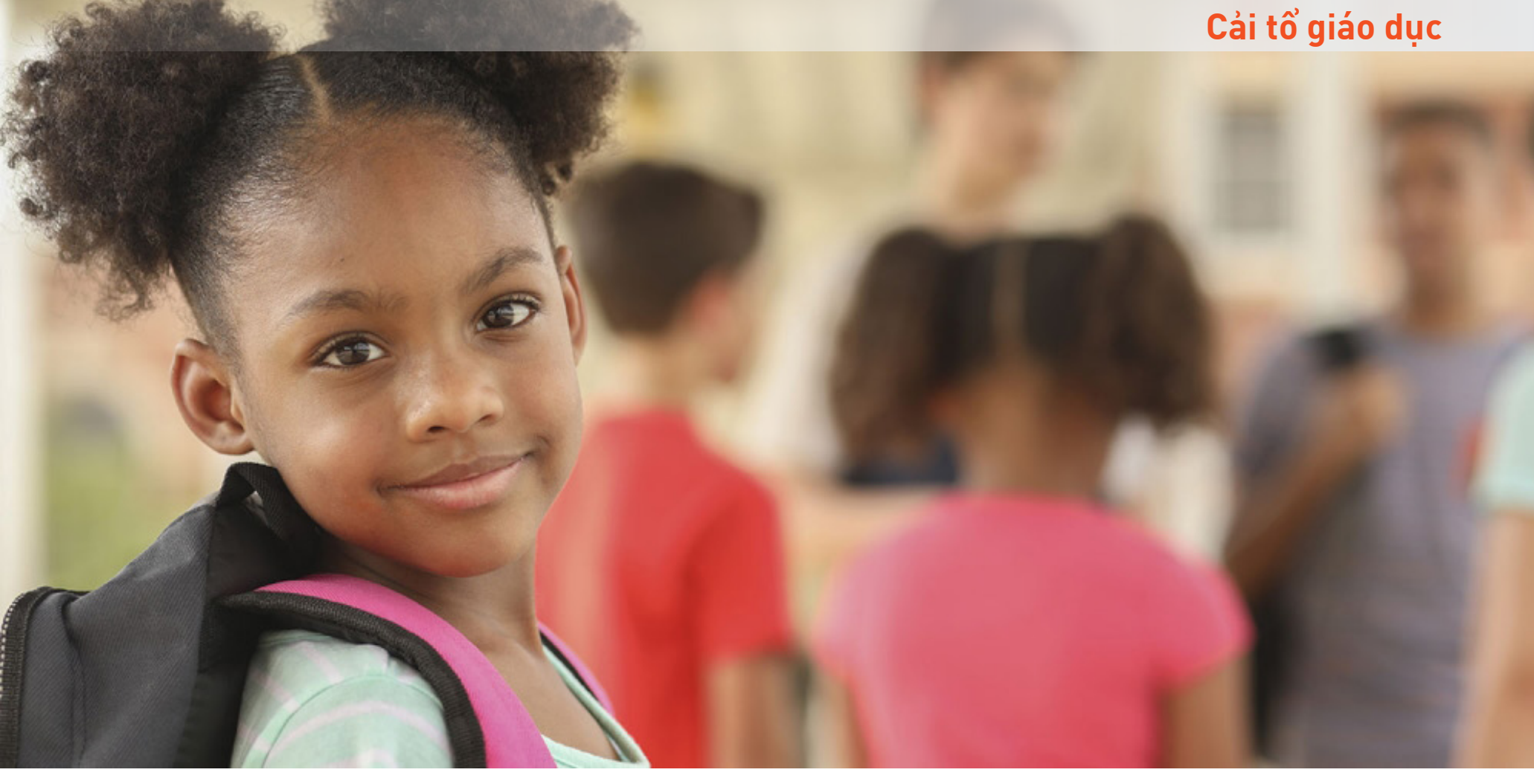

\section{LộI ÍCH LÂU DẢI CỦA GIÁO DỤC MẦM NON}

${ }^{1}$ Usable Knowledge I Hà Thanh Mai dịch

Một nghiên cứu kết nối giữa cải cách chất lượng giáo dục mầm non với kết quả học tập của trẻ mầm non và học sinh cấp ba.

Các nhà nghiên cứu đã tìm hiểu về tác động lâu dài của giáo dục mầm non nhiều năm nay. Đã có một số nghiên cứu tìm ra được lợi ích lâu dài, một số khác cho rằng những gì trẻ đạt được có thiên hướng mất đi khá sớm. Kể cả khi người ta tìm ra những lợi ích lâu dài, các nhà nghiên cứu vẫn chưa khám phá được nhiều về tác động của những lợi ích đó - những biến số nào sẽ để lại tác động lâu dài và những biến số nào sẽ sớm mất đi.

Theo một nghiên cứu dài hạn mới được công bố trên tạp chí Child Development ISự phát triển của trẻ nhỏ), các nhà nghiên cứu tại Trường Sau đại học về Giáo dục Harvard (Harvard Graduate School of Education - HGSE) đã có tiến triển $1 \quad$ Nguôn: https://www.gse.harvard.edu/news/ uk/19/08/lasting-gains-preschool đáng kể trong việc xác định được mục tiêu nói trên. Nghiên cứu này kết nối giữa kiến thức và kỹ năng điều chỉnh hành vi trẻ học được ở trường mầm non trong những năm đầu đời với điểm số của những năm sau đó ở trường trung học phổ thông (THPT). Nhìn chung, các nghiên cứu cho thấy rằng việc hỗ trợ giáo viên mầm non ở những nơi có thu nhập thấp có thể mang lại tác động tích cực kéo dài tới khi trẻ học cấp ba.

Các giáo viên mầm non được tập huấn đã giúp học sinh xây dựng được kỹ năng học tập từ sớm - sự can thiệp này có hiệu quả kéo dài đến tận trung học phổ thông.

Nghiên cứu đã xem xét cụ thể một chương trình bôii dưỡng mầm non: Dự án Sẵn sàng cho Trường học Chicago (Chicago School Readiness Program - CSRP). Đây là chương trình phát triển nghề nghiệp và tập huấn dành cho giáo viên đã được thực hiện tại 35 trung tâm Head Start ở Chicago vào năm 2004 và 2005. CSRP tập trung vào việc cải thiện kỹ năng quản lý lớp học và giảm căng 
thẳng nghề nghiệp cho giáo viên nhằm gián tiếp cải thiện kết quả học tập của học sinh. Chương trình đã là minh chứng cho việc nâng cao điểm số của những học sinh tham gia CSRP khi các em học THPT.

Nghiên cứu hiện tại bởi Trợ lý giáo sư Dana Charles McCoy và Giáo sư Stephanie Jones của HGSE, cùng với Nghiên cứu sinh Tiến sĩ Katie Gonzalez, cho thấy rằng điểm THPT của học sinh cao một phần là nhờ từ vựng và kỹ năng toán các em đạt được từ nhỏ. Nghiên cứu cũng cho thấy một số tác động đến các kỹ năng liên quan đến chức năng điều hành ${ }^{2}$ của học sinh cấp THPT bao gồm các kỹ năng nhận thức trong việc kiểm soát xung động và sự chú ý. Những tác động này còn mơ hồ hơn, nhưng những phát hiện từ nghiên cứu cho thấy rằng việc phát triển kỹ năng toán học sớm, nhờ vào chương trình bồi dưỡng mâm non, có thể mang đến những lợi ích lâu dài trong các kỹ năng điều hành.

McCoy nói rằng: "Kết quả của nghiên cứu chỉ ra những tác động bền vững của các biện pháp nhằm nâng cao chất lượng cho chương trình giáo dục mầm non hiện có. Trong bôi cảnh khó khăn, nỗ lực cải thiện hạnh phúc của giáo viên mầm non và kỹ năng quản lý lớp học xuất hiện ở đây để mang lại lợi ích lâu dài cho kết quả học tập của trẻ, ngay cả khi không có hỗ trợ thêm cho việc giảng dạy."

"Kết quả của nghiên cứu chỉ ra
những tác động bền vững của
các biện pháp nhằm nâng cao
chất lượng cho chương trình giáo
dục mầm non hiện có." - Dana
Charles McCoy.

Các nhà nghiên cứu cho biết mối liên hệ giữa các kỹ năng toán học lúc nhỏ và kỹ năng điều hành về sau từng được đề xuất trong một số lượng nhỏ các nghiên cứu - hiện ngày càng tăng về số lượng. Nhưng chúng ta vẫn cần phải nghiên cứu thêm để hiểu mối quan hệ giữa các yếu tố này.

2 Chức năng điều hành [Executive functioning]: là một tập hợp các kỹ năng thuộc tinh thần [mental] bao gồm trí nhớ ngắn hạn [working memory], suy nghĩ linh hoạt và tự chủ [self-control].
Các tác giả cũng lưu ý rằng nghiên cứu này chỉ xem xét một loại chương trình cụ thể, dành cho một nhóm nhỏ học sinh. Vì thế, các nhà nghiên cứu khác sẽ cần tái lập những kết quả này trong các bối cảnh và loại chương trình đa dạng hơn.

Nghiên cứu này bổ sung thêm bằng chứng về tác động lâu dài của nhiều nỗ lực nhằm cải thiện chương trình giáo dục mầm non. Hiệu quả của chương trình được chứng tỏ sau hơn một thập kỷ cùng với những lợi ích của việc xây dựng kỹ năng tương đối đơn giản trong những năm đầu đời đó. Và loại kiến thức này là chì khóa quan trọng, nó không chỉ giúp cung cấp thông tin cho các cuộc tranh luận về “sự tàn lụi” ở trường mầm non, mà còn giúp nâng cao chất lượng trường mầm non cho số lượng trẻ em ngày càng tăng.

Đồng tác giả Jones cho biết: “Với sự gia tăng gần đây trong việc tham gia học mầm non do được tiểu bang và liên bang tài trợ, điêu quan trọng là chúng ta phải hiểu cả tác động ngắn hạn và dài hạn của các biện pháp can thiệp sớm, cũng như các kỹ năng có thể gây ra những tác động này."

\section{TÓM TẮT}

- Một chương trình bồi dưỡng giáo dục mầm non đã giúp học sinh được điểm cao hơn khi học THPT, một thập kỷ sau đó. Chương trình này tập trung vào việc hỗ trợ sức khỏe của giáo viên và kỹ năng quản lý lớp học ở các trường mầm non có thu nhập thấp.

- Một nghiên cứu mới tìm thấy bằng chứng cho thấy tác động của chương trình nâng cao vốn từ vựng và kỹ năng toán ở trẻ mầm non đã góp phần tạo nên kết quả học tập ở các lớp THPT.

- Các tác động của chương trình đối với các kỹ năng toán cũng có thể có một số liên quan đến các kỹ năng điều chỉnh hành vi lâu dài ở trường trung học.

- Nghiên cứu nhấn mạnh tác động sâu rộng của việc nâng cao chất lượng cho chương trình mầm non hiện nay. 


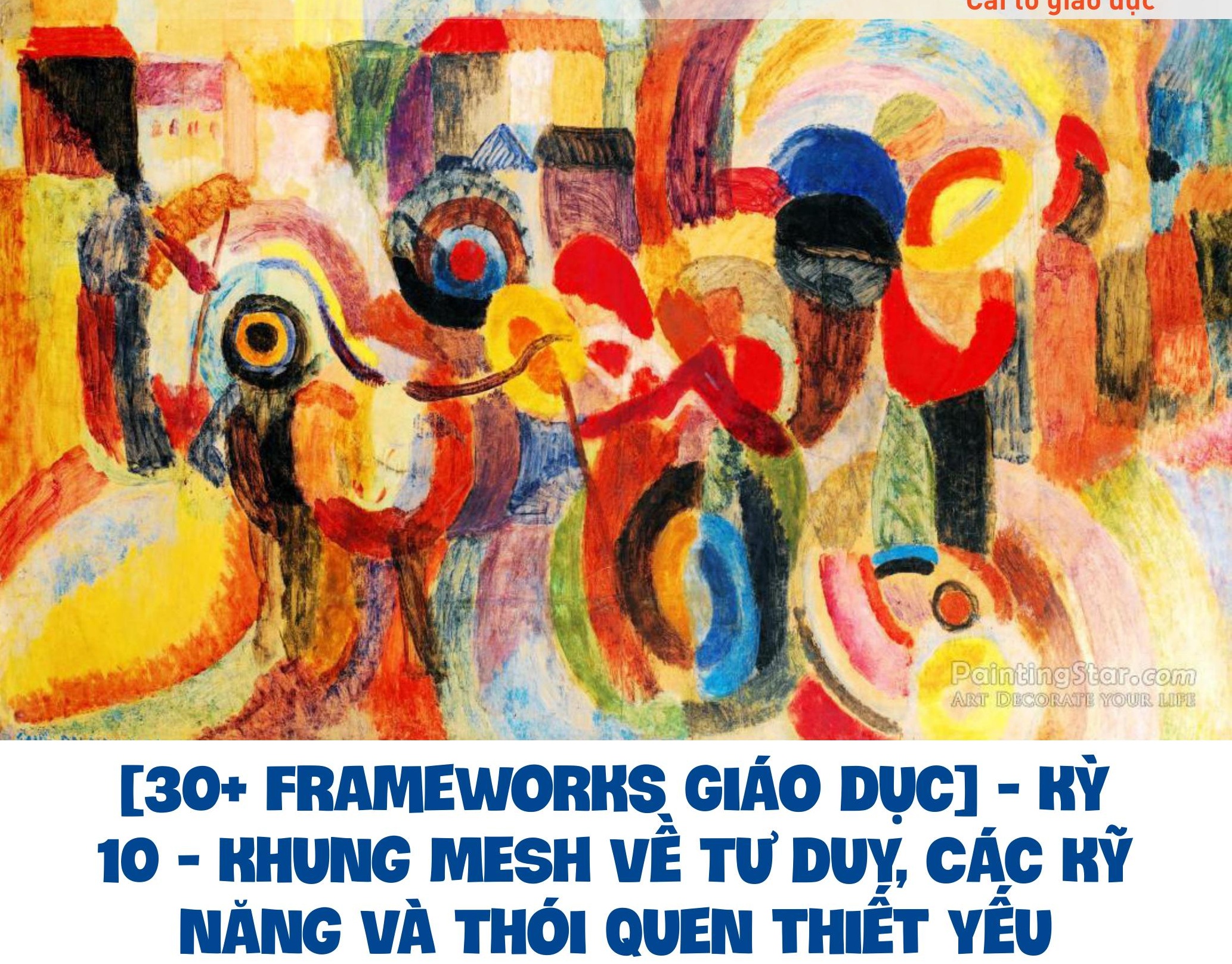

Việt Anh cải thiện; để hỗ trợ cải thiện việc giảng dạy, xây dựng chương trình, cải tiến trường học

MESH là chữ viết tắt của Mindsets, Essential Skills, and Habits

\section{Độ tuổi: K-12}

Phát triển bởi: Tổ chức phi lợi nhuận Transforming Education ${ }^{1}$ hợp tác với các hạt trung tâm của bang California, Hoa Kỳ.

\section{Mục đích:}

Để giúp các nhà giáo dục, các nhà hoạch định chính sách và phụ huynh hiểu và đánh giá điểm mạnh của học sinh và xác định các lĩnh vực cần

1 Transforming Education: là một tổ chức phi lợi nhuận hỗ trợ các nhà giáo dục trang bị cho học sinh các kỹ năng xã hội-tình cám. Xem thêm tại: https://www.transformingeducation.org/

Áp dụng: Được các hạt Trung tâm của California (Fresno, Garden Grove, Long Beach, Los Angeles, Oakland, Sacramento, San Francisco, Santa Anal sử dụng để đánh giá năng lực tình cảm-xã hội của học sinh như một phần của cải tiến hệ thống.

\section{Bối cảnh:}

- Một nhóm 9 trường học khu của các hạt trung tâm tại California đang nỗ lực tìm ra một phương cách nhằm đưa các giá trị cảm xúc-xã hội của học sinh trở thành một trong các chỉ số phát 
triển, cũng như là một yếu tố trong hệ thống giải trình trách nhiệm nhà trường.

- Khung đo tập trung vào các tư duy và năng lực nội tâm, năng lực hướng ngoại quan trọng cho sự thành công lâu dài. Các năng lực và tư duy này có thể đo lường được và có thể đưa vào giảng dạy trong nhà trường.

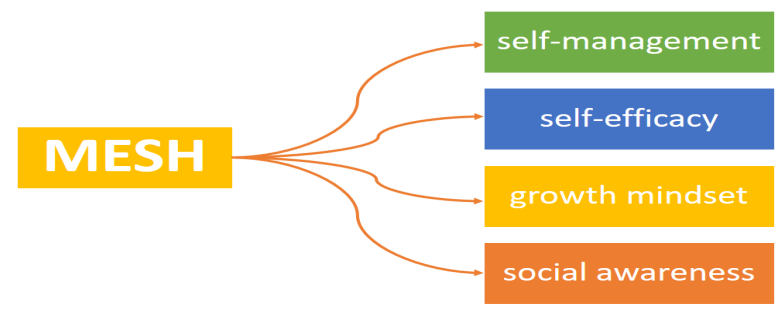

\section{Công cụ đo (Xem tài liệu tham khảo số 1):}

- Với học sinh lớp 5-12, có hai phương thức

- Khảo sát học sinh: đo được tất cả các năng lực MESH

- Khảo sát giáo viên: đo được hai năng lực có thể quan sát từ bên ngoài lquản lý bản thân và nhận thức xã hội)

- Các cách thức tiến hành khảo sát và những câu hỏi thường gặp trong quá trình khảo sát (khi nào, tại sao và cách sử,.. I và cách diễn giải kết quả khảo sát.

\section{Tài liệu tham khảo:}

1. Transforming Education. (April 2016). Measuring MESH: Student and teacher surveys curated for the CORE Districts. Retrieved from: https:// www.transformingeducation.org/wp-content/ uploads/2017/04/160406 MeasuringMESH ForRelease2.pdf

2. Transforming Education. (Dec 2015). Ready to be counted: The research case for education policy action on non-cognitive skills. Gabrieli, C., Ansel, D. \& Bartolino Krachman, S. Retrieved from: https://www.transformingeducation.org/ wp-content/uploads/2017/04/ReadytoBeCounted Release.pdf

3. Transforming Education. (April 2017). Introduction to social and emotional learning. LaRocca, R. Retrieved from: https://www.transformingeducation.org/wp-content/uploads/2017/04/Introduction to SEL 4Competencies.pdf

4. Transforming Education. (Sept 2016). Expanding the definition of student success: A case study of the CORE Districts. Bartolino Krachman, S., Arnold, R. \& LaRocca, R. Retrieved from: https://www.transformingeducation.org/ wp-content/uploads/2017/04/TransformingEducationCaseStudyFINAL1.pdf

\#EdLab

\#moingay1frameworkGiaoduc \#LearnToLearn \#CultivatingEducationalPractices

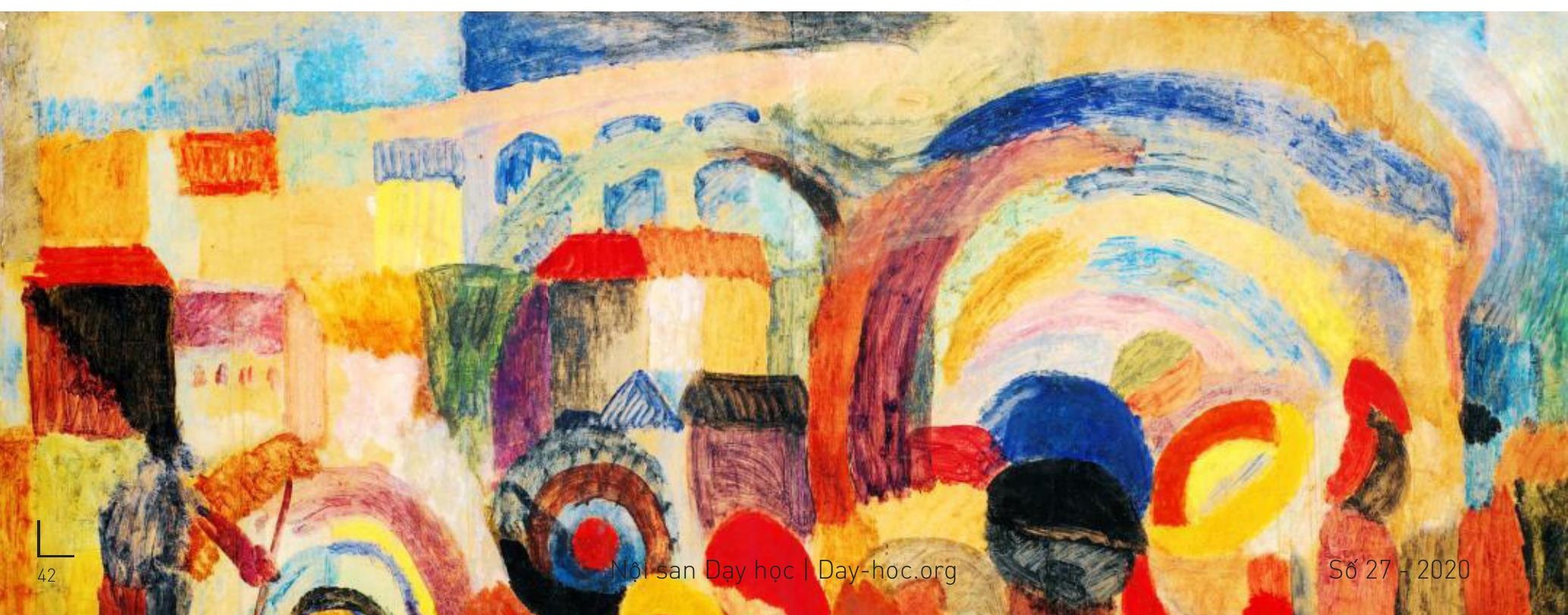


1Leah Shafer | Ayden Lê dịch

Trẻ nhỏ ngày càng đa dạng về ngôn ngữ. Làm thế nào các nhà giáo dục đầu đời có thể xây dựng một môi trường học tập an toàn và đảm bảo sụ̣ phát triển phù hợp?

Quá trình trẻ nhỏ học cách trò chuyện với người khác thật đáng kinh ngạc. Trẻ không chỉ phải hiểu ngữ pháp và từ vựng mà còn phải phát triển sự hiểu biết về văn hóa chẳng hạn như: trình tự trong cuộc hội thoại, nhận biết được người đối thoại và cách dẫn dắt một câu chuyện như thế nào.

Đối với những trẻ dưới 5 tuổi học song ngữ (Dual language learners) với ngôn ngữ mẹ đẻ không phải là Tiếng Anh - quá trình đó diễn ra phức tạp hơn. Những trẻ nhỏ này phải liên tục điều hướng giữa hai ngôn ngữ và văn hóa, đồng thời học các quy tắc của cả hai. Mặc dù lợi ích của đa ngôn ngũ là rất rõ ràng, nhưng những trẻ học song ngữ có thể bị kì thị hoặc bị trêu chọc vì sự khác biệt, dẫn đến những cản trở trong sự phát triển của trẻ.

Khi sự đa dạng ngôn ngữ bùng nổ trên toàn thế giới, các nhà giáo dục đầu đời cần phải chuẩn bị để giúp học sinh học song ngữ có thể đáp ứng và vượt qua những thách thức này. Bài viết này sẽ đưa ra nhận định từ Paola Uccelli² - chuyên gia về đọc viết, ngôn ngữ học và giáo dục song ngữ về cách tạo ra môi trường thuận lợi giúp phát huy khả năng của những trẻ học song ngữ cũng như gia đình của chúng.

\section{Sự đa dạng của ngôn ngữ trong giáo dục} đầu đò̀i

1 Nguồn: https://www.gse.harvard.edu/news/ uk/18/04/multilingual-preschoolers

2 Paola Uccelli: là một giáo sư tại trường Harvard Sau Đại học về Giáo dục. Cô nghiên cứu sự khác biệt về văn hóa xã hội và cá nhân trong sự phát triển ngôn ngữ và khả năng đọc viết trong suốt những năm đi học. https://www.gse.harvard.edu/faculty/paola-uccelli
Theo Uccelli - Giáo sư tại tại Trường Harvard Sau Đại học về Giáo dục cho biết: "Các cơ sở giáo dục đầu đời cần phải là những nơi mà trẻ và gia đình biết rằng họ có 'quyền được nói', rằng họ sẽ được lắng nghe và phản hồi với sự quan tâm và tôn trọng,". Tuy nhiên, việc tìm được những chương trình mầm non chất lượng cao, đáp ứng về mặt văn hóa và ngôn ngữ là không hề dễ dàng.

"Sụ̣ trộn lẫn," (Code-mixing) hoặc kết hợp các ngôn ngữ khác nhau trong một câu, không phải là dấu hiệu của sự chậm phát triển mà là do những trẻ học song ngữ đang học song song hai ngôn ngũ cùng một lúc và thường chỉ biết một số từ nhất định trong một ngôn ngữ.

Ba trong số mười trẻ em trong các chương trình Head Start $^{3}$ xuất thân từ các gia đình có ngôn ngữ chính không phải là tiếng Anh và dân số học tiếng Anh đang gia tăng trên khắp mọi nơi. Nhưng một thực tế là có rất ít nhà giáo dục mầm non thông thạo nhiều hơn một ngôn ngữ và được đào tạo về sự đa dạng về văn hóa và ngôn ngữ.

Bên cạnh đó, trẻ song ngữ ngày nay cũng nói một loạt các ngôn ngữ mà ngay cả các nhà giáo dục song ngữ hay chuyên về song ngữ cũng không có ngữ cảnh để hiểu được ngôn ngữ của trẻ.

Và mặc dù có bắt nguồn từ những mục đích tốt, bạn bè và giáo viên vẫn thường đưa ra nhận định không công bằng về mặt trí thông minh và tính cách đối với những trẻ và gia đình nói song ngữ dựa trên cách họ nói.

\section{Ba bài học thiết yếu cho các nhà giáo dục đầu đò̀i}

3 Head Start: là một chương trình miễn phí, được tài trợ bởi liên bang. Chương trình này được thiết kế cho trẻ 3-5 tuổi, nhằm thúc đẩy sự sẵn sàng đi học cho trẻ em từ các gia đình có thu nhập thấp. 
Để tạo ra các lớp học tích cực, các nhà giáo dục cần bám theo một số điểm cơ bản về những trẻ song ngữ.

- "Sự trộn lẫn," (Code-mixing) hoặc kết hợp các ngôn ngũ khác nhau trong một câu, không phải là dấu hiệu của sự chậm phát triển mà là do những trẻ song ngữ đang học song song hai ngôn ngữ cùng một lúc và thường chỉ biết một số từ nhất định trong một ngôn ngữ.(Ngay cả khi lớn lên, một số trẻ có thể có thế mạnh về một số ngôn ngữ nhất định trong một số trường hợp nhất định - ví dụ, chỉ có thể cầu nguyện bằng tiếng Tây Ban Nha và chỉ đọc bằng tiếng Anh.) Vì thế, ở lứa tuổi Mầm non, việc trộn lẫn hai ngôn ngữ để truyền đạt một ý là điều bình thường.

- Tương tự, sự phát triển ngôn ngữ không bị trì hoãn vì những học sinh này đang học nhiều hơn một ngôn ngữ cùng một lúc. Trẻ em đơn ngũ̃ và song ngữ học từ với tốc độ như nhau. Trên thực tế, song ngữ đã được chứng minh là mang lại lợi thế: Nó liên quan đến việc thúc đẩy các khả năng nhận thức cấp cao, hiểu được nhiều quan điểm xã hội khác nhau và nhận thức về ngôn ngữ toàn diện (metalinguistic awareness).

- Nếu cha mẹ có kỹ năng tiếng Anh hạn chế, đừng khuyến khích họ sử dụng tiếng Anh ở nhà với con mình. Điều này có thể dẫn đến các cuộc trò chuyện hời hợt, bế tắc không mang lại sự kích thích đối-đáp (serve-and-return) hỗ trợ sự phát triển ngôn ngữ. Phần quan trọng nhất của giao tiếp giữa cha mẹ và con cái là chất lượng của sự tương tác, bất kể ngôn ngữ.

Thiết lập các nhóm nhỏ bao gồm cả trẻ học đơn ngữ và trẻ học song ngữ, để đảm bảo sự hòa nhập qua việc giải thích cho những trẻ chỉ biết tiếng Anh rằng những trẻ học song ngữ vẫn đang học và làm mẫu cách họ có thể giao tiếp hiệu quả với bạn bè của mình.

\section{Thúc đẩy sự hòa nhập và phát triển}

Uccelli cho rằng việc thúc đẩy một môi trường đa dạng và hòa nhập là chìa khóa quan trọng. Không gian giáo dục đầu đời nên tạo điều kiện cho trẻ em nói về sự khác biệt và học cách sống trong một xã hội đa văn hóa. Các nhà giáo dục nên đồng thời hỗ trợ phát triển tiếng Anh và coi trọng ngôn ngữ mẹ đẻ của trẻ.

\section{Đối với các nhà lãnh đạo về chương trình:}

- Viết một tuyên bố với sứ mệnh đánh giá rõ ràng sự đa dạng và hòa nhập ngôn ngũ.

- Bất cứ khi nào có thể, hãy tìm những người $a m$ hiểu về sự phát triển và đánh giá song ngữ, có kinh nghiệm làm việc với các gia đình đa văn hóa, hoặc nói tiếng mẹ đẻ của trẻ em để tham gia vào chương trình chương trình giáo dục.

- Hỗ trợ nhân viên đạt được những kỹ năng và phát triển về mặt chuyên môn trong các lĩnh vực văn hóa, ngôn ngũ̃ và sự đa dạng.

- Biên dịch sách, âm thanh và tài liệu số theo ngôn ngữ của trẻ. Làm nổi bật những nội dung này trong toàn khắp lớp học.

\section{Đối với Giáo viên hoặc Bảo mẫu trong Lớp học:}

- Khuyến khích trẻ nói ngôn ngữ mẹ đẻ của chúng trong những môi trường phù hợp, chẳng hạn như với bạn bè cùng trang lứa hoặc riêng với giáo viên. Tránh yêu cầu trẻ nói chuyện công khai trước một nhóm nếu trẻ cảm thấy không thoải mái khi làm như vậy.

- Thiết lập các nhóm nhỏ bao gồm cả trẻ học đơn ngữ và trẻ học song ngữ, để đảm bảo sự hòa nhập qua việc giải thích cho những trẻ chỉ biết tiếng Anh rằng những trẻ học song ngữ vẫn đang học và làm 
mẫu cách thức chúng có thể sử dụng để giao tiếp hiệu quả với bạn bè của mình.

- Học các từ hoặc cụm từ chính bằng ngôn ngũ̃ chính của trẻ học song ngữ và hát các bài hát trong lớp bằng các ngôn ngữ đó. Đừng chỉ sử dụng ngôn ngữ mẹ đẻ của trẻ để rèn luyện kỷ luật; thay vào đó hãy sử dụng vào giải trí và học tập.

- Cung cấp các "không gian tự do ngôn ngữ" như những giờ nghỉ cần thiết để trẻ có thể chơi mà không cần nói chuyện, sử dụng các khối, đất nặn, hoặc các câu đố, V.V.

- Chú ý và trả lời khi trẻ nói với bạn bằng ngôn ngữ mẹ đẻ, ngay cả khi bạn không hiểu lời.

- Điều chỉnh ngôn ngũ̃ phù hợp với trình độ phát triển tiếng Anh của trẻ em. Nếu một đứa trẻ vẫn đang trong giai đoạn đầu học tiếng Anh, thì hãy đơn giản hóa các thông điệp, lặp lại các từ quan trọng và sử dụng cử chỉ để hỗ trợ. Nếu có thể, hãy sử dụng chính ngôn ngữ mẹ đẻ của trẻ.

- Mời các gia đình đa ngôn ngữ tình nguyện tham gia lớp học của bạn và sử dụng ngôn ngữ mẹ đẻ của họ. Đồng thời yêu cầu các phụ huynh viết nhãn cho các vật dụng trong lớp học bằng ngôn ngữ mẹ đẻ. 


\section{Ban Biên tập Lộn xộn}

\section{Hoàng Anh Đức}

\section{Dương Phú Việt Anh}

Nguyễn Linh Chi

Phạm Mai Hằng | Orenj Technology

Nguyễn Trần Thu Uyên | Viện Nghiên cứu và Đào tạo Việt Anh Khương Thị Hồng Cẩm | Học Viện Kangan, Úc

Ngô Trọng Đại | Trường Trung học Vinschool

Lê Nguyên Khang | One On One English

Hà Thị Thanh Mai | Trường Mầm non Hoàng Mai (Q. Gò Vấp TP.HCM)

Chương Nguyễn | THPT Chuyên Lê Quý Đôn Vũng Tàu Nguyễn Tiến Đạt | Công ty CP PTGD POMATH

Phùng Thị Ngọc Lan | Hogwart

Logo / Hà Dũng Hiệp

Chếbản / Quách Anh

Liên hệ: bientap@day-hoc.org
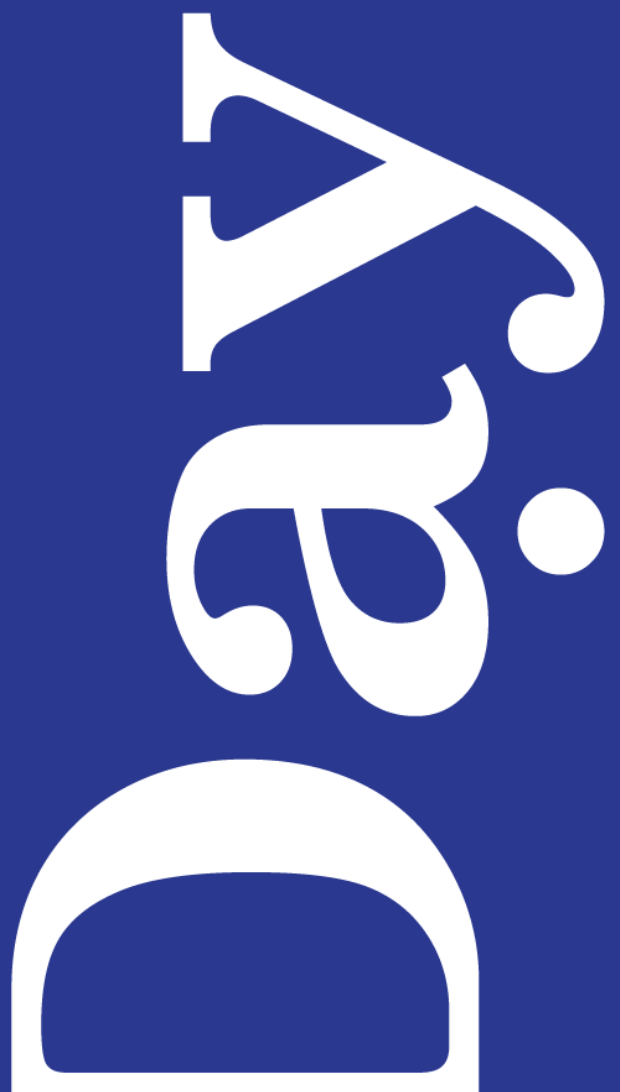


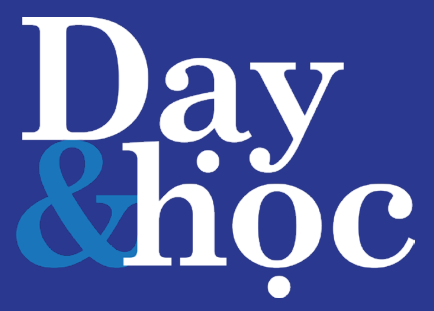

Số 27 | tháng 09 - 2020

Ban Biên tập Lộn xộn

\author{
“Học để Dạy, \\ và Dạy để Học
}

